\title{
Do governance quality and ICT infrastructure influence the tax revenue mobilisation? An empirical analysis for India
}

\author{
Hrushikesh Mallick ${ }^{1}[$
}

Received: 7 November 2019 / Accepted: 18 May 2020 / Published online: 8 June 2020

(c) Springer Science+Business Media, LLC, part of Springer Nature 2020

\begin{abstract}
It attempts to empirically understand the role of Information and Communication Technology infrastructure and governance quality in direct and indirect tax revenues mobilisation for the combined governments of Centre, States and Union Territories of India during the post-liberalisation period of 1990-1991 to 2017-2018. Considering that the recently implemented Goods and Services Tax (GST) is not entirely different from the previous value added tax (VAT) regime in terms of revenue collections at each stages on the value added of manufacturing and sales but an extension of VAT (which existed since 2005 by most of the states and Union Territories until 1st July 2017) by bringing the services into tax net, it tries to assess on the role of institutions/governance and use of modern ICT infrastructures in realisation of greater tax revenues for the combined government. The findings surprisingly reveal that ICT infrastructures and governance quality have no significant positive effect on the overall tax revenue collections. This contrary outcome could be possible when there is greater scope for tax payers to easily escape out of the tax net by carrying out the transactions outside the ICT system or without relying on to the use of ICT infrastructure and leaving no trace behind.
\end{abstract}

Keywords Governance quality - Modernised methods of tax collection - Tax efforts · Combined Government in India

JEL Classification $\mathrm{A} 1 \cdot \mathrm{H} 2$

Hrushikesh Mallick

hrushi@cds.ac.in; hrushi_isec@yahoo.co.in

1 Centre for Development Studies (CDS), Prasanthnagar, Thiruvanathapuram, Kerala 695011, India 


\section{Introduction}

Despite India's consistent ascendancy as one of the fastest growing developing economies in the world for quite a long period of time (for almost one and half decades except the present recessionary milieu since 2019-2020 which is characterised by sluggish pace of domestic demand and recession in major economies in the world and again outbreak of Covid-19 exposing the world economy into serious economic perils), ${ }^{1}$ it is believed that the quality of governance and provisioning of public goods and services in India continue to be the modest. There exists a greater complementarity relation between the two. Effective governance can go a long way to ensure the efficiency in the delivery of public services and similarly, optimal availability of public infrastructure especially in terms of the wide-accessibility of modern technologies (such as ICT or digital facilities) can also to a large extent ensure the efficiency in delivery of public services through greater accountability and transparency in information between the service providers, government agencies and the intended beneficiaries of those public services. ${ }^{2}$

Most of the studies while examining the factors influencing the tax compliances by the tax payers for greater tax revenues although admit to face practical difficulties in measuring the compliance gap (tax evasion) and obtaining the statistical information relating to the factors influencing the compliances for all the economies in general, but they observe lesser degree of compliances or higher levels of tax evasion in developing economies (Andreoni et al. 1998). This along with the economic structure (lower income base/low level of economic development), fragmented politics, weak institutional structure and low transparency drive for a low proportion of tax revenue to GDP environment for the developing economies comparing the rich

\footnotetext{
1 The novel corona virus (Covid-19) which had its origin from Wuhan city in Central China in 2019 has brought the world economy into screeching halt by the 2nd quarter of 2020 affecting all the major economic activities in the world and in turn affecting the world productivity (and hence, the global growth as per IMF is projected to be down by $3 \%$ from its $3 \%$ rate in 2019) since the great depression of 1930 s. The great depression of $1929-1932$ is estimated to have contracted the global growth by $10 \%$. International institutions like IMF and World Bank have projected the intensity of the economic effect of this current global pandemic to be more severe than the Global Financial Crisis of 2008 which reduced the global growth rate by $0.7 \%$ in 2009 . The economies are not only suffering economic losses on account of the lockdown of economic activities by their respective governments, but also it has resulted in colossal loss of human lives and sufferings across the world. The advanced countries have experienced so far the worst ever health and economic crises due to the outbreak of Covid-19 virus even they are richer in terms of their financial and human resources including possession of advanced health infrastructures compared to the vulnerable poor developing countries. Nevertheless, the effect of this health pandemic has begun to spread more severely in many developing countries of Latin America and Asia including India.

${ }^{2}$ Following Fukuyama (2013), we define governance to refer to "government's ability to make and enforce laws (establishing property right laws) and deliver goods and services to the satisfaction of public, so as to generate greater faith and confidence on the effectiveness in the working of the government institutions". The established institutions should operate in most possible efficient ways so as to ensure maximisation of social welfare. Good quality governance depends on strict implementation of the rule of laws, contributing to greater (full) faith of the public on the government and its various agencies responsible for delivery of goods and services and which has a cascading effect on the private economic activities in the society and impacting their morale. Applying the same into field of taxation, it refers to the possible ways of checking evasion and avoidance in payment of taxes to the government.
} 
economies (Besley and Persson 2014). ${ }^{3}$ Studies consider effective enforcement by tax authorities (tax administration) and availability of information about the potential tax payers, as critical factors in influencing the compliance behaviour of tax payers. In view of the absence information about the extent of improvement in effectiveness in tax administration (or efficiency in tax collection by tax authorities) and degree of tax compliances by the tax payers for a developing economy like India, this study focuses on examining the quality of governance and access to modern ICT facilities as proximate measures of the extent of efficiency in tax administration and degree of tax compliances and their role, to what extent they are responsible for improvement in the realisation of tax revenues for India.

Although over the last two-three decades there has been an acceleration in the availability and use of physical infrastructures and modern information services by all economies including India, however, India has been still facing economy-wide physical infrastructure constraints in many spheres of economic activities including the ICT infrastructure facilities. This restrains in the realisation of full benefits of digitalisation not only for the government but also for the public. These constraints can clearly be visible when it involves the synergy between the delivery of services by various public agencies and private sector's access to those services through the modern technologies. The deficiencies can be observed in accomplishing the relevant works being ultimately and successfully done by the public.

Similarly, when it comes to measuring the quality of governance for developing economies including India, there is either modest improvement or no improvement over the years. In the global corruption perception index ranking by the Transparency International, India, was ranked 79th position in 2016 among 176 countries. With its rank being slipped to 81 st in 2017 in the list of 180 countries, the Transparency International (2019) on the basis of perception of public sector corruption put it among the worst offenders in graft and press freedom in Asia Pacific Region. ${ }^{4}$ In 2018, although it could improve its position marginally to 78th most corrupt country in the world along with Burkina Faso, Ghana, Kuwait, Lesotho, Trinidad and Tobago, and Turkey, all scoring the same on the corruption metre, however, in 2019, it again slipped to 80th among 180 nations. ${ }^{5}$ It is claimed that on account of absence of clear mechanism to establish accountability, the corrupt officials in the name of public welfare improvement, channel public funds to wasteful projects which generate bribes, depleting public funds that could otherwise have been spent productively on heads such as health, education and other services. This could have

\footnotetext{
${ }^{3}$ Tax compliance depends on law enforcement, organisational design, ethics and combination of all these. Tax enforcement is a problem of law enforcement. Deterrent effects associated with penalties and probability of detection are central to tax compliance and tax enforcement. Designing an organisation to enforce tax laws has much in common with principal-agent problem. With imperfect ability to monitor, design a taxation system, audit, punishment schemes to meet desired objective of tax revenues become quite difficult.

${ }^{4}$ The index uses a score from 0 to 100 . Zero is extremely corrupt, and 100 is most transparent with India's score being 40 in both 2016 and 2017 from a score of 38 in 2015.

${ }^{5}$ The information is directly accessed from Transparency international (2019). https://www.transparen cy.org/cpi2019.
} 
potentially benefitted the poor in most significant ways. ${ }^{6}$ Poor quality of governance and lack of progressive modern infrastructure and digitalisation facilities are likely to have important bearings on the fiscal performance of national governments of developing economies. Weakness in both the factors not only leads to low levels of revenue realisation but also increases their fiscal deficits. The developing economies' governments fail to control their fiscal deficits more especially when they fail to achieve efficiency in government expenditure allocations and not being able to restrain total expenditures in response to increasing population and cost of provisioning of public goods and services on account of escalation in inflation.

Since a developing economy like India with vast geographical size has been experiencing a rapid population boom (although the population is growing at a lesser rate in the recent decades comparing prior years of 1990s), it requires provision of various basic public services and facilities by various concerned governments over which they retain their authority in terms of their jurisdictional setting. ${ }^{7}$ Facilitating the public with provisioning of access to modern information and communication technologies (ICT) assumes critical importance in enabling the public to comply with various governmental laws as per various official/departmental bureaucratic rules along with provisioning of most convenient public transportation facilities with proper carrier/container capacity for smooth movement of goods and people across locations and equipping the nation with necessary roads and infrastructures. However, the provisioning of these basic facilities is still far away from meeting the realistic demand in terms of both quantity and quality of public services for a developing economy like India. This can be assessed considering the per capita availability of various infrastructure indices made available with the World Bank and other national statistical official agencies suggesting congestion in accession to most of the public services. As a case in point, this problem is being more severely pronounced when the tax payers while trying to comply with implementation of new taxation policies at the initiation of every round of new major indirect taxation reforms carried by the government in India like introduction of VAT and GST, the tax payers have to struggle very hard besides overcoming other constraints in meeting the desired compliances. In recent times, on several occasions, it is reported that even after several months of implementation of GST in India, the situation has remained so precarious that the tax payers are not able to have proper access to the government's e-filing tax network system either to e-file their taxes or even timely claim the input tax credits on their input purchases while filing the taxes on the sale of their final goods. This clearly reflects the capacity constraints facing the government and tax administration authorities in equipping with adoption of suitable ICT infrastructure facilities to the public on the one hand, and more particularly,

\footnotetext{
${ }^{6}$ Young people in corrupt societies have little incentive to acquire new skills which are crucial for them to acquire for a good societal living. The corrupting role of money in political financing unduly exerts influence on the political system of the nations.

7 The population was growing at a rate of $2.2 \%$ in 1991, but it has slowed down to $1.6 \%$ in 2011 (Census of India 2011).
} 
when the authorities are trying very hard to enforce new tax policy changes to be complied by the tax payers (manufacturers and sellers) on the other. Given the prevailing uneasy and disruptive environment, this could reflect severe financial resource constraint and skilled personnel crunch facing the governments to meet and improve the physical and administrative capacity necessary for a growing and populous economy. This in effect is failing to pass the test of economic efficiency, when the government radically aims at amending the economy's tax policies before the system is ready to accommodate the change. Moreover, this has also resulted in less realisation of revenues than its potential levels for both the central and state governments what the authorities had expected prior to the implementation of indirect tax policy changes, i.e. GST.

The financial resource constraint being faced by the governments over the years including the recent period gets reflected from the higher level of fiscal deficits and increasing debt of the central government relative to the states and the Union Territories (UTs). This weak fiscal situation has arisen despite the continuous efforts by both the governments to maintain fiscal discipline by putting ceilings on their respective fiscal deficits and debt levels and increasing efforts for greater tax revenue collections as per their changing fiscal rules from time to time. Therefore, to make appropriate provisioning of public infrastructures for common access, both the centre and states governments (including UTs) need to have more financial resources. The mobilisation of financial resources among other things hinges on methods and mechanism of collecting tax revenues with proper deployment of quantity and quality of modern physical infrastructures, efficient tax collectors, transparency and accountability in the system (transparency in methods of collecting tax revenues by public officials and honesty and morality of the tax payers in complying with the changed tax laws), tracking of information on portion of income generated in the private sector but legally falling outside the purview of untaxed sector (which again hinges on changing structural features of the economy), simplification of the tax laws, knowledge and awareness of the citizens to comply with tax laws and financial and real punishments associated with defaults in tax payments among others.

With revolution of ICT infrastructure which seems to be the sine qua non for the global economy, this study looks at whether the use of modern ICT infrastructures has resulted in greater collection of tax revenues in view of potential contributory power of ICT infrastructures to confer towards transparency and accountability in the taxation system. When one refers to the use of modern infrastructure, it does not only include the use of modern infrastructures from government side but also constraints on the availability and accessibility of those infrastructures for the common public use (private sector). Otherwise, infrastructure capacity creation by either party without ensuring accessibility of the same by the other party on a mutual basis may put constraints on achieving the desired outcomes in an economy. The use of ICT infrastructure (digitalisation) is not only gaining importance in realisation of revenues for the governments, but also for improvement of governance quality, and services delivery by the public agencies. The ICTs are not only accounting for the rapid improvement in general service delivery, but within the context of public sector performance, they are increasingly seen as panacea to many problems that the governments are facing while trying to serve the citizens in most efficient ways in 
their respective jurisprudence. E-governance has been publicised as a means to cut costs, while at the same time it improves the quality, timeliness and access to service delivery by public agencies. ${ }^{8}$

On the other side, it is also possible for one to argue that when governments can realise greater revenues that itself could enable the government to enhance its capacity to deploy more quality physical infrastructures including modern ICT infrastructures and thereby enhancing the levels of general welfare in the economy. Apart from efficient deployment and use of ICT infrastructures, unless tax administration is efficiently complemented with the quality of governance machinery and proper institutional structure, ICT infrastructure alone may not be of adequate help to realise desired revenue productivity gains for the governments. Therefore, it is important to examine role of ICT infrastructure along with governance quality (or institutional mechanism) in realisation of greater tax revenue productivity or revenue augmentation for a developing economy like India. Placing the emphasis on quality of governance is quite significant for realisation of potential revenues, without which there will be greater leakages/wastages of public resources and tax evasion, ultimately compromising with the aggregate welfare through its distortionary consequences.

A study conducted by IMF (2016) on "Corruption: Costs and Mitigating Strategies" points out corruption imposes a greater social cost on nations as it weakens state's capacity to perform its core functions. It affects macro-financial stability, public and private investment, human capital formation, curbs on economic growth and thereby undermining the potential drivers of inclusive growth. Countries with higher corruption tend to have poor access and low quality infrastructure for a given level of public capital stock, thereby undermining the efforts to improve over the infrastructure gap and productivity of existing capital. The worldwide, bribery alone which constitutes around $1 \%$ of total corruption is estimated to cost around \$2 trillion a year, equivalent to the size of the GDP of many smaller wealthy countries like Italy and many times of $\$ 149.3$ billion received as global development aid to developing and least developing countries (2018). ${ }^{9}$ Several studies (Mauro 2004; Dreher and Herzfeld 2005; Blackburn et al. 2006; Arnone and Iliopulos 2007; Muralidharan et al. 2014) also point out that the countries that are less corrupt and maintain good transparency record achieve greater economic success in terms of higher growth, GDP levels and Human Development Index (of United Nations) based on measures such as life expectancy and years of schooling. On the contrary, studies have also evidenced positive contribution of corruption on economic growth for the developing economies (Ugur and Dasgupta 2011; Campos et al. 1999; Ugur 2014). Based on the theory of bureaucracy, experts are of the opinion that enhancing the salaries

\footnotetext{
${ }^{8}$ In a worldwide context, the policy makers have noted the role of E-governance in improving the efficiency and effectiveness of public administration including its contribution to increasing transparency in administration, reducing corruption, and increasing political participation by the citizen voters.

9 This amount reflects the net flows of official development assistance (ODA) from the Development Assistance Committee (DAC) in the year 2018 at current prices (OECD, April 2019). ODA is defined as official financing flows to promote the economic development and welfare of low and middle-income countries. Net ODA is total ODA spent minus repayment of loan principals by recipient countries. The $D A C$ is an OECD committee that serves as a forum for 30 donors and observer bodies.
} 
of the government employees can be thought of as a way to mitigate the problem of corruption and improving the productivity in public sector and that in turn can contribute to higher growth. Otherwise, if the officials cannot earn certain wage levels sufficient enough to take care of their cost of living, they are likely to recourse to corrupt practices. This view is based on the proposition that higher are the wages and salaries for the government employees, this would act as a deterrent for employees to engage in corrupt practices as this can serve as a risk of losing their jobs at the enhanced salaries (Van Rijckeghem and Weder 2002). Therefore, higher wages may contribute to productivity of public capital. In contrast, based on institution-building theories, some others advocate strong institutional measures to be in place which can check corrupt tendencies of officials (through establishment of proper legal framework as to protect the government institutions with measures such as liability of actions for officials omitting the rule of law while discharging their duties in good faith of the institution). ${ }^{10}$ However, the governments have also their own capacities to which they can raise the salaries of their employees given their hard budget constraints which they face similar to the private sector.

In contrast, the international financial institutions, such as IMF and World Bank, are also helping the governments around the world to fight against corruption, and poverty by improving transparency, accountability and suggesting timely institutional changes for better institutional and fiscal outcomes and achieve higher growth and development targets. The anti-corruption measures by various governments around the world are also providing opportunities for private technology corporate agents to innovate alternative strategies like blockchain technology. In India, it has resulted in introduction of Aadhaar card and by linking it with all other bank accounts, enabling to trace the transactions for each individual's accounts including various beneficiaries of different government cash transfer benefit programs. The technology enables to aggregate the data from various sources of government spending and contracting of public services and analyse this information for gauging the wastage, fraud, and corruption in government and also helping the governments to collect information on private properties (income and wealth) generated and tax payables. Although digital information in general is easy to modify, blockchain is thought to provide a robust immutability of not engaging in dishonest and illegal activities. This has recently come into vogue by many social welfare agencies responsible for implementation of various governmental schemes around the globe. However, despite recognition of greater effectiveness of digital technologies, it has been facing resistance and prohibition in its use by many governments on account of cyber security concerns. Therefore, its large-scale adoption needs governments' support which is necessary to fight against official corruption. Thus, the institution of government plays a critical role for efficiency in the uses of available technologies.

Technology has dramatic influence over our day today lives and almost all the activities in various sectors of different capacities. Public finance, which involves an art of efficiently raising and allocating financial resources to deliver optimal public

\footnotetext{
10 A credible threat of prosecution for corrupt acts requires investigative agencies, police, prosecutors and judges who are not themselves corrupt. Moreover, institutions should be founded on transparency of objectives and operations, rule of law and regulation.
} 
services and benefits, redistributing income and smoothing of ups and downs of the business cycle, has been undergoing dramatic digital revolution. Digital revolution has been influencing and reshaping governments' activities and programs. How governments need to effectively manage these activities crucially hinges on their ability to collect, process and act on an array of information on how much enterprises/firms and workers earn, how many people are unemployed, who qualifies for the benefit of government's program. Digitalisation has been aiding governments and the people to collect enormous amounts of required information on a mutual exchangeable basis. It benefits governments to design their revenues and expenditures policies. Similar to many other developing emerging economies, people in India are able to realise subsidies and welfare payment benefits directly in their bank accounts, by uniquely linking it with their biometric identifiers. When the tax authorities collect information on sales and wages on a real-time basis in several advanced and emerging economies, this not only gives an immediate insight into the state of the economy, but also government's fiscal position, enabling them to chart out immediate and long term future policy strategies.

While there may exist a jerky side of digitalisation due to the concerns of privacy, confidentiality and cyber security, at the same time, it raises broader debate over inequality of its access and redistribution of its real benefits. With the help of a standardised simple structured personal information reporting format, through wide use of digitisation and electronic interface, tax authorities can be able to access vital and accurate sources of information collected by other private and government agencies on areas like personal bank-based transactions and interest incomes accrued. This is possible when governments take efforts in encouraging and compelling the people to carry out transactions only through banks. ${ }^{11}$ A study by Hondroyiannis and Papaoikonomou (2017) reported that an imposition of restriction on cash withdrawals in July 2015 in Greece triggered a surge in card payments by consumers resulting in an unprecedented realisation of VAT revenues. Based on quarterly time series data, they empirically established that a $1 \%$ increase in the share of card payments in private consumption resulted in almost $1 \%$ higher VAT revenues through greater compliances, and, lowering the VAT rate and promotion of card-based transactions can lead to greater tax buoyancy. When Hondroyiannis and Papaoikonomou (2018) extended their analyses to cover 19 Euro Area economies for the same

\footnotetext{
11 Government of India (2019) since 2017 in its Union Budget announcement had been making special policy provisions to discourage cash based transactions by varying the limits on cash receipts and payments by businesses/individuals to curb the flow of black money and promote digital economy. Starting the financial year, 2017-18 the central government had set a cash transaction limit of Rupees 3 lakhs for receipts, but with an immediate amendment to the Finance Bill in the next month, it reduced the receipt limit to Rupees 2 lakh. Individuals receiving cash non-electronically above this limit in respect of a single transaction or transactions relating to one event or occasion from a person, outside the banking system or post-office or governments, it is treated as a punishable offence. The extent of penalty initially was a sum equal to the amount of such receipt, liable to be paid by the receiver. This penalty did not apply to a person who proved that there were sufficient reasons for such contravention. Similarly, the Central Board of Direct Taxes (CBDT) with an amendment of the tax rule effective from 1st September 2019 has reduced the cash payment limit to Rs 10,000 from Rs 20, 000 which was effective since 1st April 2018-19 for an individual for any single payment or aggregate of payments to other individuals in a day.
} 
period 2003q1-2016q4, the analysis corroborated with similar evidence for individual economies that an increasing share of card payments in private consumption expenditure improves the VAT tax compliance. A higher share of card payments in consumption expenditure may therefore be expected to improve the efficiency of consumption taxes like VAT.

Just like the authorities receive real-time data on wages paid by employers and determine tax liabilities of workers and companies, similarly electronic invoicing system can allow immediate access to data on firm sales and purchases. Many countries' governments are also using invoice-matching software programs to verify value added tax (VAT) refund claims of merchants associated with tax amounts filed by them. Based upon usual tax input credit method of computing the tax liabilities for sellers under GST, the GST collection in India also follows a similar tax invoice information matching method of collecting taxes from tax payers. These are significant measures towards resolving the problem that has long thwarted the tax collectors around the world. These technological solutions have also promising benefits for fragile economies, where conflict and corruption hamper the tax collections and receipts of benefit payments. Mobile technologies are also relied upon as direct and effective mediums to deliver public services, carrying transactions, track medical records when admitted as patients and disseminate other vital information. With better data collection, access and increased data processing power, technological improvement and their adoptions can allow the governments to improve ways of collecting taxes. Electronic filing makes it easier and cheaper for taxpayers to fill out tax returns and also for governments to speedily process those. It saves people's time in running to revenue offices, relies on officials and pays bribes to lower their tax payments.

The introduction of new taxes on goods and services in India had its effects in increasing the number of registered taxpayers by around 38\% over the existing numbers in less than 1 year since its introduction. ${ }^{12}$ The greater merit in using this modernised infrastructure is that data on each individual taxpayer can be aggregated from a wide range of government and corporate sources in powerful ways, as well as individual digital footprints which can be established to build up a profile of taxpayers' total income. This information can later be used to assess the accuracy of information reported by individuals. Such improved data processing capabilities can be utilised on a massive scale to improve revenue mobilisation potentials and its accrual forecasts. Digital technologies, including electronic payment systems, not only lower the cost of tax collection but also create the potential for expanding the tax bases.

\footnotetext{
${ }_{12}$ As on 2 March 2018, a total of 1.03 crore taxpayers had registered under GST, which include 64.42 lakh taxpayers who had migrated from the erstwhile tax regimes and 39.56 lakh new registered tax payers under GST. https://economictimes.indiatimes.com/news/economy/policy/over-1-03-crore-businesses -registered-under-gst-government/articleshow/63232433.cms?from=mdr.
} 
The introduction and use of biometric technology in India has immensely helped various welfare agencies in government to extend social benefits to intended beneficiaries on a massive scale in a more transparent way. Since this technology enables to properly monitor and record biometric characteristics, such as fingerprints, it allows more accurate authentication of individuals' identity at lesser expense from a wide range of databases. The same technology if can be deployed to assess the risks of non-compliance and predict the behavioural impact of new tax and spending policies, it can go a long way to enhance the tax compliances. The use of biometric authentication and digital payment systems for paying government subsidies to intended recipients can reduce the reliance on blunt redistributive instruments. ${ }^{13}$ The theory and evidences suggest that a low and reduced rate of VAT on necessities, while aiming at benefiting the poor, it largely benefits the wealthy even more. Therefore, a better targeted tax payment mechanism may surmount the redistributive goals in a more efficient way, providing the reliable necessary benefits to the poorest. This implies that there exists greater scope of making sales taxation, land taxes and other taxes more progressive in India by restricting the applicable concessional taxes for individuals to some minimum size of land holdings and increasing the tax rates for people crossing those thresholds. This may serve as an enabling measure for the poor to afford for purchasing land for shelter and entrepreneurship and other productive purpose like agriculture.

\section{Broad structure of taxation system in India}

Indian fiscal federalism based on constitutional principle follows separation of tax powers between the centre and state governments. ${ }^{14}$ The central government has the power to levy major broad-based and mobile tax bases. The major direct taxes by centre include taxes on non-agricultural personal incomes and wealth, and corporate income, while major indirect tax sources are excise duties on manufactured products, customs duties and services taxes without a proper coordination mechanism with the states in collection of indirect tax revenues. The excise duties on manufactured products have evolved as VAT on manufactured goods. The major tax powers assigned to states include taxes on agricultural incomes and wealth, sales taxes, excises on alcoholic products, taxes on motor vehicles and on transport of passengers and goods, stamp duties and registration fees on transfer of property and taxes

\footnotetext{
13 The Direct Benefit Transfer program, launched in 2013 in India, significantly changed the way subsidies, and payments are delivered by transferring the benefits directly into bank accounts linked to the beneficiaries' Aadhaar biometric identity. Subsidies for cooking gas are one such program. In April 2017, citizens required to include their Aadhaar number in tax filings and required to link their individual bank accounts with the Aadhaar.

14 The nature of federal polity, assignment of tax powers and tax sharing arrangements can influence incentives for revenue mobilisation and structure and administration of taxes in both central and state governments. Prior to 11th Finance Commission, some specific taxes collected by the Centre were only being shared with the states. As a result, central agency did not put utmost care in tapping optimum revenue potential from those tax sources, and this led the states to suffer in revenue shares from the centre. Therefore, 11th FC recommended the centre to share revenues with states from almost all the sources.
} 


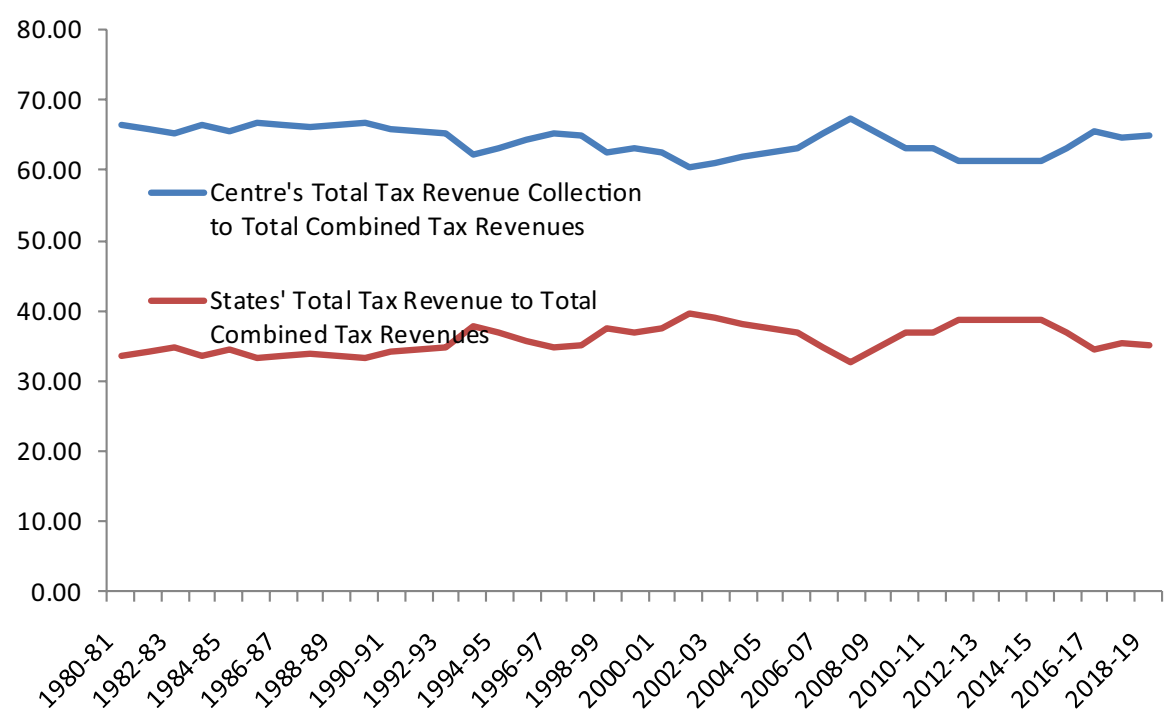

Fig. 1 Share of the centre and states and UTs in combined total revenue collections. Source: Handbook of statistics on Indian economy (2018-2019)

and duties on electricity. States also have powers to levy taxes on entertainment and incomes earned from professions, trade or employment. Some states have retained these powers with themselves, while others have assigned some of these revenue bases to their local bodies. The state's list also includes property taxes and taxes on entry of goods into a local area for consumption and use or sale. The states, however, mostly assign these revenue sources to local bodies. Except few specified services, taxes on which were assigned to states such as entertainment tax, passengers and goods tax, and electricity duty, the constitution of India did not explicitly recognise and assign the power to tax the services to any lower governments till as late as 2003. However, since all residuary tax powers were assigned to the central government, this authority became the basis for the centre to levy taxes on selected services from 1st July, 1994. In 2003, with 88th amendment to constitution, the central government was specifically assigned the power to tax on services. The following description would give a broad understanding of trends of direct and indirect taxes levied by the combined government.

Figure 1 reflects that the central government consistently collects a greater percentage of total combined tax revenues of around $65 \%$ and the rest, 35\% of total revenues is collected by states. This reflects asymmetry in revenue raising power between the two governments in India. Out of the total tax revenues collected by the centre, as per the recommendation of 14th Finance Commission of India, central government shared almost $40 \%$ of total tax revenues with states. This was a 


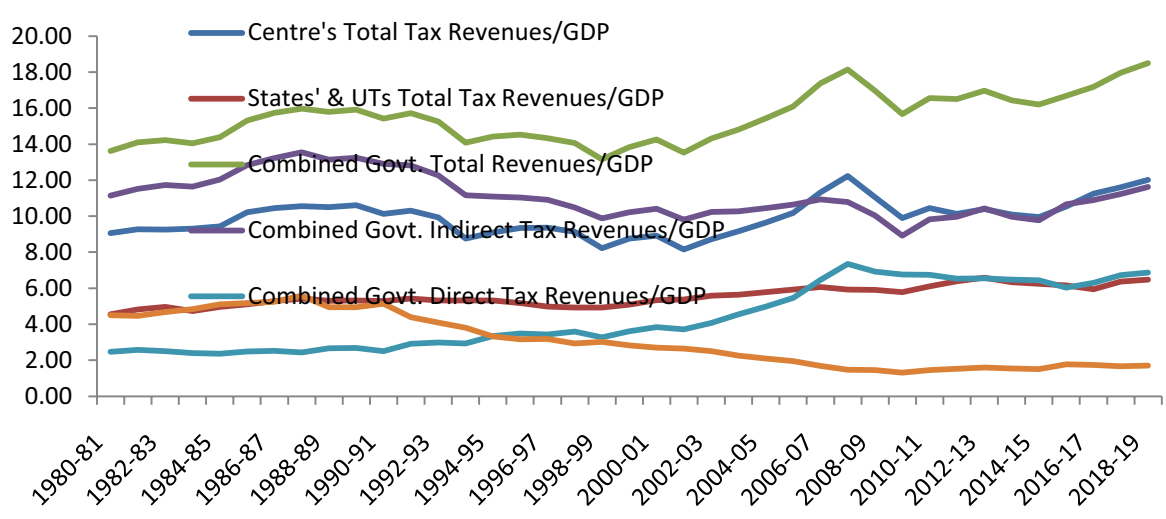

Fig. 2 Centre, states \& UTs (direct and indirect) tax revenues as a percentage to GDP. Source: Handbook of statistics on Indian economy (2018-2019)

substantial jump in states' share from $32 \%$ as recommended by 13th Finance commission. This is an effort by the central government to ensure greater financial empowerment of states under a framework of cooperative fiscal federalism.

The combined tax revenue as a percentage to GDP over the years shows an increasing trend along with combined direct tax revenues to GDP\% (as shown in Fig. 2). It reveals that the direct tax revenue to GDP\% has been leading the overall trends of total combined tax revenue to GDP\% since the period, 2002-2003 than the prior years. In 2018-2019, out of $18 \%$ of total combined revenue to GDP\%, the centre's collection of revenues as a percentage of GDP constituted around $12 \%$, while states' tax revenue constituted the rest of $6 \%$ of GDP. Similarly, indirect tax revenue as a principal revenue source of combined government which constituted a little less than $12 \%$ of GDP, the rest is accounted by direct tax revenue out of a little over $18 \%$ of total revenues of both the governments to GDP. The figure also indicates there is a change in the composition revenues collected for the combined government. In earlier period, relatively a greater percentage of revenues was being mobilised from indirect sources, but now source has shifted from indirect to direct sources. ${ }^{15}$

Further, as can be seen in Fig. 3, it is the central government which is found to enjoy the maximum share of revenues in combined direct tax revenue collections, while both the states and UTs are converging to almost to have an equal amounts of tax revenues shares in respect of indirect tax revenues comparing centre's share.

Figure 4 reflects that centre's indirect tax revenue collection suffered its share in relation to its own total revenue collection as direct tax revenue has witnessed a relative increase comparing its indirect tax revenue collections. For states, it is the indirect tax revenue shares which are maintained almost at a stable proportion. For centre, indirect tax revenue to its total revenues which was at 78\% in 1980-1981 has gone down to $49 \%$ in $2018-2019$, while for states, it was $89 \%$ in $1980-1981$ and has

\footnotetext{
15 This is despite the fact that a major percentage of collection of revenues still continues to come from indirect tax sources, which constitutes more than 1 and $1 / 2$ times of direct taxes when expressed in indirect taxes as a percentage to direct taxes.
} 


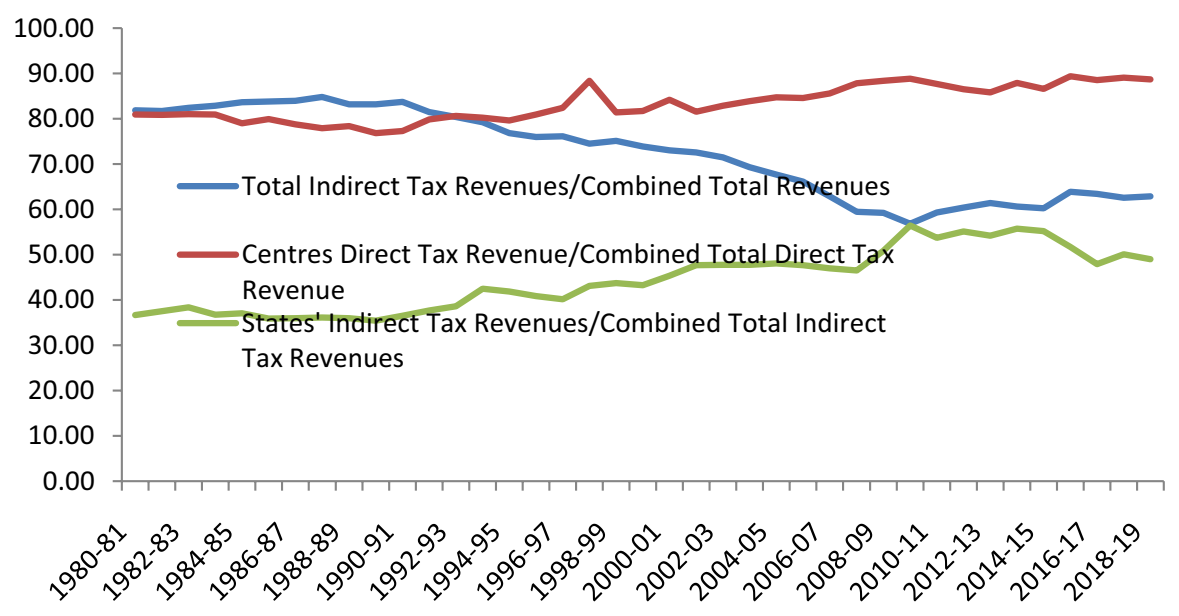

Fig. 3 Centre's share in combined direct tax revenues and states and UTs share in combined indirect tax revenues. Source: Handbook of statistics on Indian economy (2018-2019)

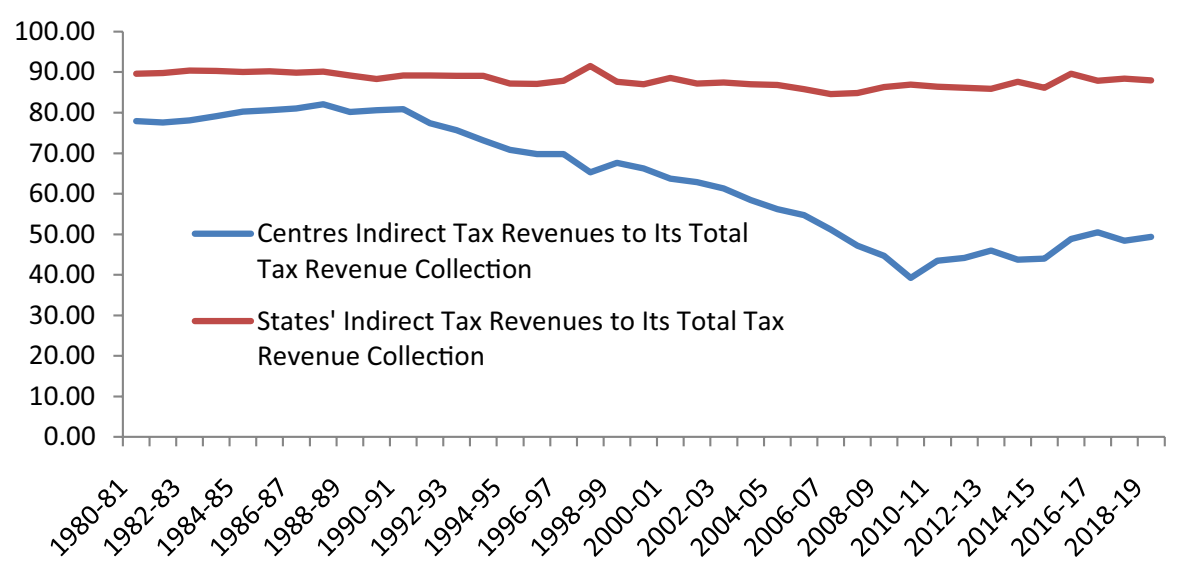

Fig. 4 Indirect tax revenue shares of centre and states in their respective total revenues. Source: Handbook of statistics on Indian economy (2018-2019)

marginally decreased to $88 \%$ in $2018-2019$. The falling trend on indirect revenue share is majorly on account of reduction of import and export duties on account of the liberalisation policies pursued at the insistence of IMF, World Bank and WTO and competitiveness strategies adopted by other countries globally in a globalised 


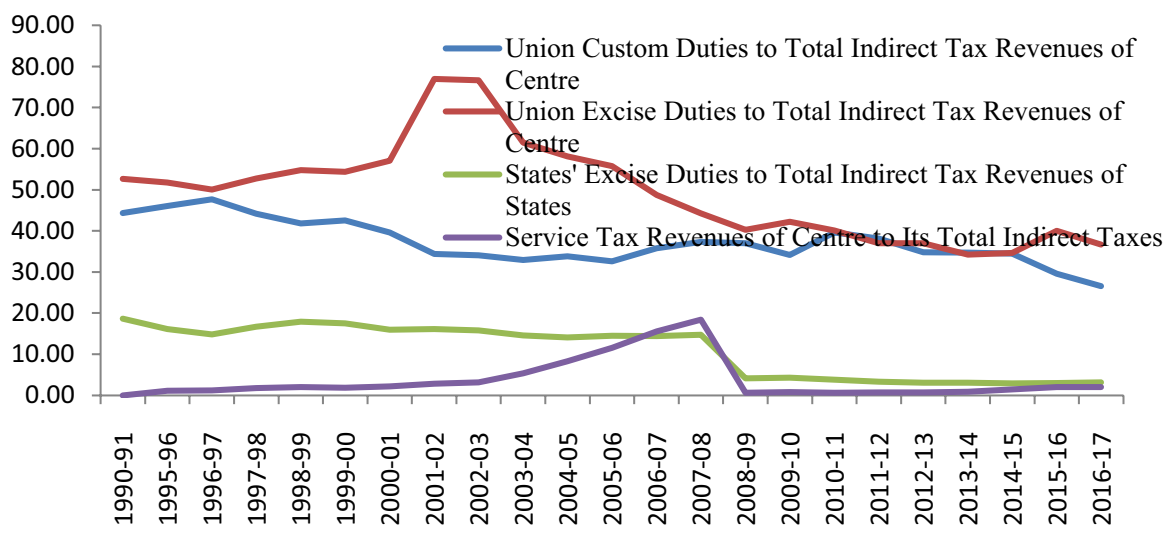

Fig. 5 Union custom duties and excise duties of centre and states \&UTs. Source: Indian public finance statistics (2018-2019)

era. This also gets reflected from relative share of custom duties in proportion to total indirect taxes collected by the centre (shown in Fig. 5).

\section{Contrasting the present indirect tax regime of GST with the previous regime of VAT}

VAT, a dual tax regime, featuring with plethora of tax rates on various ranges of goods, with a very limited degree of harmonisation in rates across different states in India on their value additions at different stages of their sales in the chain, beside central government imposing excise duties at the manufacturing level on both goods and services. ${ }^{16}$ The states did not enjoy any power to tax on services and thereby breaking the chain in production in their value additions. This problem was common and obvious when many services go as inputs into the production and sales of many other goods and thereby breaking the value addition in the chain of sales before it is ultimately consumed. Further, since central tax authority imposes taxes on manufacturing and state authorities impose taxes on sales at different stages sales and production, therefore, there is greater likelihood that it can result in tax on taxes on value of goods by different taxing authorities and at different stages before the good is being sold by the retailer to the ultimate consumer. ${ }^{17}$ Such cascading effect of taxes leads to distortion of productive activities and unlawful reporting or even non-reporting of tax liabilities, sometimes resulting in low output and low tax revenues for both central and state governments, ultimately straining the government finances and thereby, compromising with economic growth. These scenarios were

\footnotetext{
16 VAT is governed by respective state Acts. Every state had a separate and distinct VAT act reserved for their states. VAT registration is compulsory for dealers having turnover exceeding Rs 5 lakhs (or increased limit of Rs 10 lakhs in some states). On registration, dealers are allotted a unique 11 digit TIN (Taxpayer's Identification Number) based on their PAN used for direct taxation.

17 This tax is also known as central value added tax (CENVAT), new name of MODVAT.
} 
also intensely observed under the sales tax regime, prior to the implementation of VAT at the state levels. Therefore, to have a comprehensive indirect consumption tax regime, it required a coordinated reform effort of both the states and centre in reforming the state sales taxes along with reforms in the central excise duty.

The states were persuaded by the central government to rationalise their tax systems along the lines recommended by a study group from NIPFP led by Bagchi (1994). The government of India had appointed a State Finance Ministers' Committee to make the recommendations to phase in VAT regime in a time bound frame. The committee, which was subsequently transformed into the Empowered Committee of State Finance Ministers, recommended that the states adopt floor rates to minimise the "race to the bottom". However, the committee recommended VAT implementation in 2003 but continued to be postponed until April 2005. The delay in its implementation by states was largely attributed to the perceived revenue losses by states on account of input tax credits under VAT regime. However, implementation of VAT in April 2005 extended the sales tax only up to retail level with credit allowed for the taxes paid on intrastate purchases used for all intrastate and interstate sales. The interstate sales tax, that is, the central sales tax (CST), continued in the same form, pending a proposal for its phase out within 2 years of VAT introduction. Thus, many characteristics of sales taxation regime continued to prevail in VAT regime such as non-uniform tax rates, tax bases falling outside the scope of VAT including services taxes and customs duty. Gasoline and diesel fuel (which contribute around $40 \%$ of the sales tax) were kept outside the purview of VAT.

Given the sequence of indirect tax reforms, GST is conceived to be a game changer. It tried to legislate the laws to bring the services under the tax net of the states and eliminate the cascading effects of taxes by engaging two tax authorities to impose taxes concurrently than sequentially at different stages of production and value additions in the supply chain under a dual control mechanism of indirect tax collection. ${ }^{18}$ Both the central, states and UTs tax authorities are levying the taxes together at a uniform rate for both the goods and services (with 5-6 differential rates on a range of goods on the basis of their necessity and luxury). It provides an opportunity to the tax payers to file their tax returns on a single interface (single server connected to the web) to both the taxing authorities and thereby breaking the barriers in trade and commerce across the state borders (aiding to create a single common market). This is intended to help unleash the productive potential of economic activities with an aim to achieve higher growth and realise the true tax revenue potential for all the governments. Since the inception of the discussion on GST by the Government of India (2000) in its budget (2000-01) for its introduction, its implementation procedures had undergone several rounds of revisions along

\footnotetext{
18 GST has a dual control mechanism of assessing the taxpayers. Each assessee would be assessed only by one authority. Taxpayers are shared between assessment machinery. 90:10\% basis for turnover up to 1.5 crore, where states would assess $90 \%$ of business and for turnover above Rs 1.5 crore on a 50:50\% basis implying both the centre and states would have equal shares in assessing businesses.
} 
with debates about rate setting which consumed significant amount of time before it finally got implemented on 1st July 2017. It being purely a destination based tax, tax revenues collected at the state borders by the central government agencies through the IGST mode on commodity imports/exports, the revenues are being shared with state governments \& UTs where the goods are being finally consumed. It is claimed as the largest indirect tax reform in the history of India. The reform mandated integration of entire nation's diverse tax portfolio into a single taxation system. However, its introduction has given rise to massive complexities in developing an IT platform, to handle not only the diverse tax systems of 36 States/Union Territories \& Union Government, but also needed providing a single interface for more than one crore taxpayers for their GST compliances. The major difference of the present GST regime over earlier indirect tax regime is that the states and the Centre both collect revenues concurrently with almost at same rate under GST sacrificing their respective flexibilities in levying the taxes. ${ }^{19}$ The proponents of GST claim that "one of the fundamental features of GST is to achieve seamless flow of input credit across the chain (from the manufacture of goods till it is consumed) and across the country. The money in the economy is circulating as a network of pipes through which water is flowing. The banking system manages this network, and the efficiency of this system is known as liquidity".

However, it needs to be assessed and validated to what extent the present GST regime has accomplished the intended objectives of introducing a robust indirect taxation system of the country. In its initial implementation stages, it has given rise to several infirmities with regard to settlement/fixation of tax rates on various products and uncertainties in its procedural implementation. The government has been trying to settle the rates on different products and other issues on a step by step basis by frequently adjusting and readjusting with tax rates depending on the demand of various interest groups and sectors. As a result, there appears an unreasonable biasness towards some sectors by imposing a higher tax rates and lack of attention on sectors or products that deserves equal treatment. For instance, there was no rationality for a product like cement to be differentiated from any other goods of basic importance or necessities, while luxury goods like jewellery attracted a tax rate of only $3 \%$. Thus, if cement attracted a maximum GST rate of $28 \%$, how it can make the home construction affordable for the homeless, more especially in a context, when the Central Government is trying to ensure shelter for the poor under various central government schemes. The people who are just at the margin of above the poverty line but wished to construct their own shelter, high tax rate should not stand as a burden or barrier for construction of new home projects. After all, the use of products like cement is associated with creation of more new jobs and welfare of mass through their forward linkage and therefore should have received due consideration. It was pronounced that GST would prove to be revenue productive and it would greatly benefit the consumers and consumer states by making them realise higher revenues. This issue, however, calls for greater scrutiny as cascading effects

\footnotetext{
${ }^{19}$ Central Board of Indirect taxes and Customs (CBIC) under the department of revenue under the Ministry of Finance is the nodal national agency (erstwhile Central Board of Excise \& Customs) responsible for administering customs, GST, Central Excise, Service tax and Narcotics in India under GST regime.
} 
of taxes on prices seem to be mostly absorbed by the manufacturers and the vendors without passing same benefits of price reductions to the consumers. This gets reflected from increasing trend of general price levels after GST implementation. There are many countries in the world which have also shown similar experiences. This may imply that GST has not made any greater contributions of keeping down the overall inflation rates in the economy since its implementation.

Under GST regime, all tax transactions are digitised and stored on a central database, easily amenable to better collation on an accrual basis. However, in spite of entrusting a special agency to provide responsible services to tax payers, businesses are facing challenges in filing their tax return. There were instances when returns could not be filed, and refunds to exporters could not be processed and anomalies in the rate structure resurfaced. In addition, business are also complaining of several hurdles in tax payments as they have to file monthly returns along with a final annual returns which comes to filing of around 37 returns in a year and allowance is made for business below certain threshold level of turnovers to adopt for the composition scheme. Many contentious issues like invoice matching, single return, etc., are yet to be addressed properly. Having rushed into GST implementation without adequate preparation, the government had initially suspended many provisions relating to tax collection at source, tax deduction at source and many other new provisions were rushed in. These inefficiencies annoyed the taxpayers when the government tried to be strong on enforcement. Small taxpayers continue to complain of complexities in laws. The petroleum products, alcohol, tobacco and real estate are still to be brought into the ambit of GST which is a real challenge. The enforcement machinery is yet to come to the grips of complexities and ground realties. There are greater volatilities in the monthly realisation of GST revenues. The states are falling short of their revenue targets under GST, and they are complaining off non-receipt of compensation receipts from the centre. There are also problems with the formulae for refund of unutilised input tax credit for the manufacturers/sellers on account of zero-rated exports. It seems that, the government needs to do a lot more on legislation, interpretation, rationalisation of tax rates, streamlining refund procedures and exemptions for exporters, and so on. The GST Council has been meeting up frequently to take decisions for easing of the compliance burden, grant upfront exemptions to the exporters and streamline the rate structure. Despite several shortcomings, the e-tax system by offering an electronic registration, filing of returns, return computations and payment, as well as education and information to the taxpayers, it is likely to considerably reduce the cost of compliances. Therefore, the present study focuses in evaluating the influence of modern electronic system on tax revenue generations in India as electronic system is likely to contribute to the efficiency, transparency and accountability in tax collection and administration by the government officials and improve the compliances by the tax payers and thereby enhancing the tax productivity. 


\section{Reflections from theory}

Governance in relation to taxation is usually defined as a mechanism in which tax evasion and tax avoidance can be minimised (Morrell and Tuck 2014). It establishes a relationship between the enforcement pressure (legal framework) and compliance by the tax payers. Effectiveness in the enforcement of taxation laws is made possible by mutually linking up with other government agencies and regulatory agencies (third parties). Equipped with better information, one can expect better enforcement of taxation laws and less tax evasion (more transparency) and hence greater revenue realisations. This may require a greater deployment of ICT infrastructure. However, without good governance, ICT may play a trivial role in tax administration. The good quality governance can predominantly shape taxation system of a country and provide better revenue realisations. Good governance is an outcome of an efficient administration, trust in government and political stability. Lack of three things may undermine the emergence and development of an efficient taxation system.

While emphasising on a comprehensive survey of theoretical literature on linking the reliance on modern ICT infrastructure and the extent it induces greater tax compliances and therefore contributed to raising tax revenues, the theoretical contribution is undoubtedly absent. Even public finance literature emphasises on a strong tax administration which by inducing greater tax compliances can raise revenues for the government, however, the literature is largely silent on how to lay a strong enforcement mechanism for developing countries when the overall governance or institutional quality is weaker for their macro economy. Authors have pointed out that intensity of desk and field audits and, quality and availability of customer services, etc., can substantially reduce the compliance gap (taxes legally due minus actual payments or illegal non-payments), but this may be relevant for the developed economies. Even the same can be envisaged for the developing economies, but it may be difficult in practice as it requires deployment of massive resources for hiring manpower and reasonable technological diffusion.

Accountability plays a crucial role more especially when citizens are concerned about the visible link to be established between the flows of tax collection and distribution and allocation of those tax revenues. This link would justify tax collection from the public and which may help in increasing the rate of compliances. Tax compliance is usually low among the developing countries, where people neither trust that the government is concerned about their interest nor do they have the trust for a wise utilisation of mobilised revenues. Thus, when voluntary compliances are hard to come forth from majority of the tax payers, tax morale could take some role with government propagation. Many Latin American and Caribbean and South and Southeast Asian countries (Bangladesh, Pakistan, Nepal, Malaysia, Cambodia, Indonesia, Laos, Sri Lanka and Philippines) are low performers in regard to raising government revenues comparing the advanced countries. A better tax administration/ governance would of help to build up the confidence of the taxpayers leading to improvement in tax compliances and mutual cooperation among both parties.

In examining the determinants of compliance cost, Slemrod (1989) observed that taxpayers' hours part of the compliance cost (including dollars spent for hiring 
professional assistance) goes up with taxpayer's marginal tax rate. Therefore, the optimum enforcement can be reached where the enforcement elasticity of tax revenues is equal to marginal resource cost (compliance and tax administration costs) to the incremental revenue raised. Thus, the design of an efficient taxation requires taking into account the information on marginal cost of compliance and administration and the marginal social value of public spending.

According to some, the enforcement of tax laws strategically interact with statutory tax rates (Keen and Slemrod 2017). A higher marginal tax rate which has the tendency to induce evasion can be dampened by undertaking more effective administration. On the contrary, Keen and Slemrod suggest that the best response to weaker administration is to set the tax rate at a lower level and best response to a higher tax rate requires greater administrative efforts. ${ }^{20}$ Thus, the elasticity of taxable income with respect to tax rate is endogenous to enforcement activities. Higher is the elasticity of taxable income to tax rates (because of higher welfare cost) and higher is the enforcement elasticity of raising tax revenues, there is a strong case for raising additional revenues by spending additional resources on enforcement rather than raising tax rates. And when this is supplemented with lower enforcement cost, it would naturally favour enforcement actions. In a similar line, Gemmell and Hasseldine (2014) viewed that additional enforcement is undesirable to the extent that it leads to tax induced reduction in true income resulting in distortion in production and shifting the taxpayers from evasion to resort to avoidance. In this context, in order to evaluate the response of VAT compliance gap to administrative expenditures, a study by IMF (2015) estimated the enforcement elasticity for (27 EU member and Japan) during 2000-2011. Finding the response of compliance gap with respect to the enforcement cost is negative and significant; they provided the elasticity estimate to be about .17. Based on a theoretical model, Bruno (2019) concluded that good quality political institutions are not a sufficient condition for tax enforcement or tax compliance. On account of endogenous role of tax morale, government could be pushed ex-post towards poor or no tax enforcement. Contrastingly, when good political institutions are not accompanied with better information about the enforcement of tax collection, there is scope for co-existence of poor tax enforcement, low tax compliance and weak tax morale. Bruno (2019) model predicted that whenever there is high uncertainty over the proportion of agents evading taxes (which occurs in institutionally weak societies) and the sunk costs the government must sustain for tax enforcement are high. Wherever there is low morale, there is low tax compliance. ${ }^{21}$ Thus, it happens

\footnotetext{
${ }^{20}$ In response to increase in corporate tax rates in Pakistan in 2009, Waseem (2018) showed that it has resulted in greater evasion in payment of taxes by the firms to the government, resulting in lesser realisation of revenues for Pakistan government than the levels of revenues existed without the increase in tax rate. The increase in tax rate on the formal business corporations resulted in drastic reduction in the number of formal partnership firms within a period of 3 years from the change in tax policies implying exit into informality (in-formalisation). Even it did not result in exit from the formal partnerships for certain firms; the changes in tax policies reduced the firms' earnings to the extent $50 \%$ over the period before the change in tax policies. This had also resulted in income shifting in favour of sole proprietorship business and no discernible income shifting towards corporate business, even after removing tax disadvantages for partnerships in corporations. The author attributed the reduction of revenues on account of changes in the behavioural response of firms in their reported earnings to the tax evasion.

21 Tax morale is defined as voluntary compliance with tax law and creating a social norm of compliance.
} 
that where institutions are sound and tax evasion is costly (with an efficient judiciary system), then tax morale rises spontaneously. So it is the institutional system desired by the society (as a part of social custom) which determines the individual human behaviour and their morale. In a society with full tax compliance, which is extreme and an ideal system, the role of tax administration would be restricted to the provision of facilities for citizens to discharge its responsibilities. In case of non-compliance, the tax administration will have to play the role of policeman. However, on account of lack of resources where it cannot play the role of a policeman to all taxpayers, tax administration has to work out for a voluntary compliance strategy and fight against the tax evasion (Savica et al. 2015).

Concerning indirect taxation, Yitzhaki (1979) observed that tax causes substitution effect unless demand for the taxed commodity is inelastic. Optimal taxation theory enables to fix the tax rates for commodities which minimises the substitution effects (Ramsey 1927). Obviously, the minimum deadweight loss is a non-increasing function of size of set of taxed commodities. At the extreme, when all the commodities are taxed at the same rate, un-altering the relative prices, one ends up with zero deadweight losses. However, major factor which prevents an increase in number of commodities is the administrative cost of taxation, which is a decision variable. The government by changing the size of the tax bases, can trade off the losses on account of administrative costs against the excess burden. The optimum level of administration is also an increasing function of tax revenues. The optimality is reached when marginal cost of raising revenues through administrative cost equals marginal excess burden (marginal cost of raising revenues) on account of change in tax rates. Evans (2003) in reviewing the literature observed that the compliance cost varies across countries, although comparability of the estimates is quite difficult on account of differences in methodology and conceptualisation (like computation of whether to resort to social or private cost of taxation).

\section{Empirical literature survey}

In the absence of literature taking into account of the role of both ICT infrastructures and quality of governance in contributing to tax revenue realisation of countries, the following discussion tries to provide an indication about the state and degree of institutional transparency achieved in developing countries in general and India in particular and their implications for greater revenue realisations. This would provide the insight about the contributions of various factors as well as required strategies for effective tax revenue realisation for the governments in a country. A host of studies relate to transparency in general and effective governance in particular, how do they contribute to better economic performance of countries. Alon et al.(2018) in their study they demonstrated that although the prevailing wisdom suggests that less corrupt and more democratic countries do economically perform better, however, they observed the studies are at best inconsistent. They build up a theory linking corruption and regime type to economic growth. Using multiple databases including Polity IV, transparency international and World Bank, for 158 countries, they showed that under autocracy (dictatorship or totalitarian regimes), corruption was less harmful 
to economic growth than under anocracy (including emerging and infant democracies). This to some extent helped to resolve some inconsistencies and contradictory results observed from existing studies on corruption and economic growth. They demonstrated that democracies had the lowest level of corruption, while autocracies outperformed anocracies economically because they embed corruption more efficiently. Therefore, the policies should minimise the disruptions and efficiency losses due to corruption during the transition from autocracy to democracy.

Considering 149 panel of VAT implemented countries both from developed and developing economies or alternatively Sub-Saharan Africa (SSA) and non-SubSaharan African (non-SSA) countries over 1970-2013, Houssa and Megersa (2017) estimated a tax effort model accounting institutional and geographical characteristics of countries. They observed although VAT adoption had resulted in significant revenue gains for all the countries, but marginal contribution of VAT was significant for SSA countries comparing other developing and developed economies. Their investigation demonstrated that tax revenue collection was found to be higher for countries with a better institutional quality-even prior to adoption of VAT. Adoption of VAT only helped to maximise the revenues for those countries. They concluded that since VAT is now adopted in almost all countries across the world, all the developing countries should focus greater attention on promoting the reforms to improve the quality of institutions that can facilitate their tax collection.

He envisaged that ICT penetration can directly and indirectly contribute to raising tax revenues: directly through greater compliances and reducing collection and monitoring cost, and indirectly through improving efficiency in resource allocation raises productivity and income. Examining an unbalanced panel data set for 157 countries for the period 1990 to 2013, Koyuncu et al. (2016) explored the impact of ICT penetration (using both the univariate and multivariate time effect models (penetration of internet, fixed broadband, personal computers and mobile phones) on tax revenue. Using both the univariate and multivariate time effect models, they observed a highly statistically significant positive correlation between ICT penetration and tax revenue. This statistical relationship was found to be valid for four ICT penetration indicators and three tax revenue indicators.

The political coups in Fiji in 2000 led a scenario of mediocre economic performance, leading to deterioration of government finances and stagnant investment levels in Fiji in September 2002. As a remedy to this, the policy makers at the IMF recommended an increase in VAT. The national government, without carrying an in-depth economy-wide impact evaluation exercise of such a policy, announced a 25\% increase in VAT in its 2003 budget. Beginning 1 January 2003, all goods and services were levied a VAT rate of $12.5 \%$. Given the setting, Narayan (2003) used a computable general equilibrium model to examine the economy-wide effects of VAT policy. He observed that while VAT improved government revenue and brought $0.6 \%$ increase in real GDP, however, it failed to address to raise investment levels. VAT actually led to a decline in investments and a reduction in real consumption and national welfare. From this, he deduced that the IMF policy was misdirected.

In view of increasing challenges being faced by the OECD countries on account of ageing population, increasing fiscal deficits and indebtedness, Belinga et al. (2014) investigated how faster economic growth can boost the government revenues 
from estimation of short- and long-run tax buoyancies during 1965-2012. They observed that the short-run tax buoyancy of aggregate tax revenues did not significantly differ from one for majority of the countries, in spite of increased tax buoyancy achieved since late 1980s and making the tax systems to better serve as an automatic stabilizer. However, they observed the long-run buoyancy to exceed one in about half of the OECD countries, implying that GDP growth had helped to improve structural fiscal deficit ratios. Corporate taxes were by far the most buoyant, while excises and property taxes were least buoyant. For personal income taxes and social contributions, short- and long-run buoyancies had declined since late 1980s and had, on average, become lower than one.

Few studies have also investigated the relationship between the use of IT and government budget performance in terms of increases in tax revenues and efficiency or targeted delivery of government services. Dzidonu (2012) while analysing the benefit of using IT to manage the operations and delivery of public sector institutions, he observed the use of IT has led to the improvement in administrative efficiency, effectiveness and productivity in service delivery, reduction in administrative, operational and transaction costs to the public including reduced cost to access information. The benefits in the use of IT in taxation were infinite as it facilitated reducing the overhead cost of managing the agencies of government responsible for tax administration, instant computation of tax liability from the use of online tax calculator, reduced cost of registering tax payers and instant generation of tax identification number. It had also significantly resulted in reduction of collusion between the tax officials and the taxpayers in regard to tax liability, fraudulent activities of tax collectors in the event of non-remittance of taxes by the tax payers and ultimately helping to boost the revenue generation by the government and reducing the cost of administration (administrative, overhead and transactional) and corrupt practices.

Dowe (2008) observed that the tax authorities around the world are using electronic tax administration systems (like e-government led solutions like electronic tax filing (e-filing) to interact with taxpaying public in tax collection, administration and compliance settings, so as to improve effectiveness and efficiency in tax administration. Given that the bureaucratic structure is very expensive for public, the use of automated systems has proven to be capable of introducing massive efficiencies for the business to process the information and file the taxes at minimal cost. Although it is recognised that the use of IT technologies is expected to yield greater tax productivity, however, it is not without its pitfalls in harnessing its benefits. It depends on quality of internet facility, availability of electricity to power the host server, cost of maintenance of ICT facilities, technical know-how by tax administering agencies and literacy among tax-paying populations (especially the lower income tax payers) and incidence of internet hackings. In Nigeria context, Oseni (2015) concluded that the use of this modern technology had considerably reduced tax evasion activities as all potential taxpayers were captured by the system. However, he was of the opinion that the use of ICT can be catastrophic if carelessly employed by both the tax payers and the tax administrators as scammers and hackers of the internet facilities can utilise the ignorance opportunities or the lax security of the system.

By conducting a comprehensive survey of literature from various empirical studies based on the individual and cross countries, Koyuncu et al. (2016) noted GDP 
per capita, the sectoral composition of GDP, the level of foreign direct investment (FDI), trade openness and the level of public debt were the major determinants of tax revenues. Macroeconomic variables such as exchange rate, inflation rate; institutional factors like corruption, law and order, voice and accountability, civil and political rights, the level of democracy, government stability, political stability and economic stability; social variables such as the educational levels, and population growth were also considered to influence the tax revenues of the governments. Considering an unbalanced panel data set for 157 countries for 1990 to 2013 and using four ICT penetration indicators and three tax revenue indicators, they verified the hypothesis that whether ICT penetration had contributed to increased tax revenues. They evidenced highly statistically significant positive correlation between ICT penetration and tax revenues by accounting other determinants of tax revenues including the time effects in the model. Keen and Lockwood (2010) considering 143 countries for a period of 25 years observed that income per capita is not determinant for VAT adoption implying this is not preserved for the rich countries. However, a country is likely to adopt VAT if it is rich in terms of agriculture sector and lower in tax/GDP ratio. IMF also played a significant independent role in adoption of VAT. Although a VAT dummy had a positive impact on revenue to GDP ratio in few equations, it had also negative impacts. However, by allowing the impact of VAT to vary with country circumstances, a more complex result emerged. The shift effect of VAT on revenue ratio was negative. The revenue gains were clearly with the rich and more opened economies.

In the Indian context, considering the period from 1980 to 1981, Rajaraman et al. (2006) attempted to estimate the tax buoyancy for most of the Indian states where VAT was implemented in all but except 8 states in 2005 . Since they traced the structural breaks occurring in 1990s for all the states, therefore, to overcome this problem they incorporated the share of industry in total output to estimate the tax buoyancy equation. They observed that the sign of the change in tax buoyancy coefficient at the break is positive in all but six states. The set of six where there was a negative change at the break included three states with (post-break) buoyancy coefficients below one: Gujarat, Meghalaya and West Bengal. In all the rest, the post-break coefficients were comfortably above one. In states which experienced a buoyancyenhancing structural break in late 1990s, the spurt in tax effort might have been an endogenous response to implementation of higher salary scales as recommended by Fifth Pay Commission, starting in 1996-1997 (with a post-break period of only 5 or 6 years going up to 2002-2003). The median tax buoyancy they estimated was 1.30 against 1.20 which was the median buoyancy assigned to the states for the period 2005-2010 as per the report of the Twelfth Finance Commission (TFC). The study pointed out that the TFC projected buoyancies underlie the deficit grants awarded to the states and therefore carry a normative component. While referring to Shome Committee's report (Government of India 2001), they observed that the fall in aggregate buoyancy across the states from 1.12 in the 1980 s to 1.04 over the period 1990-1999 can be attributed to the sectoral shift towards services.

In the Indian context, Das-Gupta (2012) had also analysed the revenue effect of VAT over sales tax regime for 29 states during 1993-1994 to 2008-2009 along with assessing the administrative efficiency and evasion proneness. He observed a 
positive impact of VAT dummy variable implying a higher secular revenue productivity of VAT compared to sales tax regime. Analysing the same issue for individual states, he observed that VAT revenue performance was positive in 15 out of 23 jurisdictions including 6 of the 10 major states (excluding AP). The revenue gains were smaller for Karnataka, Kerala and UP. In overall, even if VAT performance was positive in $2 / 3 \mathrm{rd}$ of the states, improved own revenue performance after VAT introduction occurred in less than $40 \%$ including only two major states. Using a VAT dummy and finding its consistently insignificant for individual states, he concluded that VAT did not lead to base expansion. Analysing the assessment report of CAG (2010), he attributed the loss of revenues by the states to large tax evasion by dealers on account of ineffective procedures for verifying ITC claims and detection of fake ITC claims, incomplete automation, limited electronic return filing and lack of cross verification of information in VAT returns across dealers within and across the states.

Reviewing the existing literature, it suggests that studies have mostly focussed on factors determining the compliance behaviour of tax payers, designing optimal taxation policies, distributional and welfare consequences, effects of major changes in tax policies in terms of access to new tax instrument (like VAT) and their implications for government revenues. However, it is very scarce to trace any study attempting to relate the use of ICT technology in combination with the quality of governance which can influence the flow of information between the revenue collecting authority and the tax payers and thereby influencing the tax revenues and tax efforts of the authorities through tax enforcement more especially in a developing country like India. Therefore, this study makes an effort towards this understanding by relating both the above indicators (information technology and governance quality) with the realised tax revenues at the both levels of government in India. The empirical literature is also very infrequent in both international and Indian contexts in examining the effects of revenue compliance reduction costs on account of the use of modern ICT. It is of greater relevance to understand how the revolution in ICT has got a bearing on the revenue mobilisation efforts of governments, along with controlling the role of governance or institutional factors, while trying to relate the tax revenues with the tax base of an economy, which is the subject of investigation in this analysis.

\section{Model specification}

Following the extant literature, the tax revenue function (whether indirect tax revenue on commodities consumed or direct tax revenues on incomes, wealth/capital gains and returns) can be broadly specified to depend on the institutional quality (governance/bureaucratic quality), spread of ICT, real GDP per capita income and trade openness. Strict intervention by enforcing agencies may produce better compliance outcomes, however, excess government intervention or tax authority being 
hard on honest tax payers is likely to produce dampening effect by distorting labour force participation and macroeconomic activities.

There can be a strategic complementarity between statutory tax rate and law enforcements. When there is weak governance, the best response to weaker administration is to set a lower tax rate to achieve better compliances which may to some extent complement with augmenting the revenues. Conversely, the best response to a higher tax rate requires to be complimented with greater administrative efforts. With low marginal tax rates and weak administration, tax evasion can lead to smaller revenue reliefs(gains) for tax payers and thereby incentivising the tax payers to reduce their compliance gaps ${ }^{22}$ as this may come with financial and real penalty risk (loss of reputation) of being getting caught as a tax defaulter. However, strict governance, with low tax rate may broaden the tax base by reducing the compliance gap, while the total revenue may be relatively lower than with full compliance with higher tax rates. Otherwise, strict governance with higher marginal taxes may yield big financial gains for the evader with greater losses when caught as a defaulter.

Greater intensity in the use of digitalisation and ICT technology is changing the traditional ways of carrying out modes of businesses operations. The creation of values is fundamental to ensuring that the tax system responds to these challenges. The complexities involved in certain highly digitalised business models and value creation in digitalised age have potential implication for existing international tax framework. The value addition with the use of these modernised services has given rise to the loopholes in generation of tax revenues. ${ }^{23}$ As has been emphasised in literature, digitalisation of the economy could be one of the key factors to base erosion and profit shifting (BEPS). With increasing intensity in the use of digitalisation in coordination and collection of information from third party agencies (banks and employers, etc.), it is likely to enhance greater compliances.

E-commerce can greatly encourage and support cashless transactions dramatically helping the governments to curb the black money transactions. Digitalisation provides new opportunities as well as some new challenges to tax policy and administration beyond the international tax system. As a result, the rise of non-standard work includes the growth of gig and sharing economy and this can greatly affect the tax compliance and revenues mobilisations. While technologies like blockchain give rise to both new, secure methods of record keeping, at the same time, it also facilitates use of the crypto-currencies which pose risks to the gains made on tax transparency. This is a grey area of research in taxation which needs investigation for

\footnotetext{
22 Compliance gap is defined as the difference between amount of taxes which is legally due and what is actually paid by the tax payers.

23 The governments around the world are facing pressure on account of advent of globalisation and increasing use of e-commerce in international tax regime. Dramatic and vast growth of e-commerce, sale and purchase of commodities has been eroding the revenue base. Increasing use of smart phone and internet getting cheaper are augmenting the problem of revenue erosion. The business income is being taxed by source country, and personal income is being taxed by resident country majorly put the developing economies at disadvantages.
} 
policy to ensure that authorities harness the opportunities that these changes would bring in while ensuring the ongoing effectiveness of the tax system. It will be important to give specific consideration on how policy changes can be implemented in developing countries to take into account their particular circumstances.

It is not only that tax revenues respond to the tax base, tax revenue as a development policy strategy may also respond to economic growth and the size of the informal sector in the economy and dependency ratio. ${ }^{24}$ Tax rates as part of fiscal policy instrument are likely to affect productive efficiency and thereby the economic growth and growth rate in turn are also likely to affect tax revenue potential of an economy. There can be a simultaneity relationship between tax revenue and growth rate. With increase in trade openness, nations are competing with each other to attract more investment and trade which result in reduction of corporate taxes and taxes on import of raw materials. The globalisation emphasises on the need to minimise both efficiency cost and compliance cost of the tax system. This has been resulting in decline in overall revenues for governments as a result of cuts in tariffs and duty on imports and exports, and it is also true that with reductions in export duties, it is likely to reduce the export prices in international markets and thereby promoting international trade and economic growth and hence increased tax revenues.

We specify the tax revenue models in three common ways. Equation 1 is expressed in terms of per capita tax revenues, and Eq. 2 is expressed in terms of tax revenues as percentage of GDP. In order to examine whether structural features of the economy matter in collection of tax revenues for the governments, the model to incorporate the structural features of the economy, it considers non-taxed sector (share of agriculture in total output), where both the states and central governments do not levy any taxes. In respect of services, it is the central government which had been enjoying the privilege of imposing taxes on services sales and with recent introduction of GST, services sales have been incorporated as a tax base for the states also. Therefore, it considers combining services output with industrial output by treating them as similar activities for tax treatment and treated share of agricultural output as a separate independent variable which is not subject to imposition of direct taxes or indirect taxes unless it happens to be capital input purchases for agriculture sector, which are subject to some indirect tax levies. Further, two types of models are specified to be estimated for each kind of revenues such as aggregate combined tax revenues of both centre and states and UT governments, for combined direct tax revenues and combined indirect tax revenues of centre and states and UT governments and total state indirect tax revenues. It is to be noted that it is the centre which collects a maximum chunk of revenues through direct taxes on private income and wealth; it also collects a major share of indirect tax revenues from total indirect tax sources, while it is the states and UTs which collect major percentages of their total tax revenues mainly from indirect sources on sales. It is the centre which collects the custom duties, excise duties, service taxes on indirect ways

\footnotetext{
${ }^{24}$ We tried to capture the size of the informal economy and structural changes from the share of agricultural income in total national income and share of both industry and services in total national incomes. Since tax revenue especially direct taxes are likely to depend on size of total workforces in various employments, due to lack of unemployment statistics, we considered dependency ratio as a proxy.
} 
and the maximum contribution of tax revenues comes from indirect sources than direct sources, which is almost a characteristic feature of taxation for most of the developing countries around the world. Our objective is to examine whether the use of modern ICT has resulted in greater tax revenue collection for the combined governments, controlling the tax base and quality of institutional factors. Now, the study specifies both the considered models Model A and Model B on total combined tax revenues of centre and state governments. Model A is in per capita terms attempts to understand the factors in the flow of revenues to the government on a per capita basis, while model B is in terms of tax efforts to assess how tax effort responds with different macroeconomic factors in the economy. The first one can be treated as a supply side equation, and the second one can be treated as a demand side equation for determination of government revenues.

Model A

Tax Revenue Per Capita $=\alpha_{1}$ Governance Quality $+\alpha_{2}$ ICT $+\alpha_{3}$ RGDP Per Capita $+\alpha_{4}$ Trade Openness $+\alpha_{5}$ RGDPgr $+\alpha_{6}$ Dependency ratio $+\alpha_{7}$ Agri Share $+u_{1}$

\section{Model B}

$$
\begin{aligned}
\text { Tax Revenu2GDP }= & \alpha_{1} \text { Governance Quality }+\alpha_{2} \text { ICT }+\alpha_{3} \alpha_{3} \text { LRGDP Per Capita } \\
& +\alpha_{4} \text { Trade Openness }+\alpha_{5} \text { RGDPgr }+\alpha_{6} \text { Dependency ratio } \\
& +\alpha_{7} \text { Agri Share }+u_{2}
\end{aligned}
$$

whereas, governance quality may affect the tax revenues positively or negatively, ICT and per capita income are supposed to have positive influence on revenue collection, trade openness is supposed to have negatively affect the tax revenues due to competition among nations to reduce both export and import duties, growth rate is supposed to have positive influence on tax revenues, and dependency ratio and agricultural share are likely to adversely affect the tax revenue realisations.

\section{Data sources and descriptions of variables used}

The coverage of the analysis spans from the period from 1990-1991 to 2017-2018, where there are lot of reform measures undertaken in areas of fiscal policy specifically in respect of taxation and external sector, and monetary policy measures. With recommendation of Tax Reform Committee (TRC 1991), a number of systematic and comprehensive tax reform measures were initiated at the central level from December 1991 along with initiation of other market-based economic reforms. Since then, there are significant tax reform measures being initiated over different periods. With an aim to relate the use of ICT infrastructure and governance quality with tax revenue mobilisation, the key reason of starting the period of the analysis from 1990 to 1991 is that the statistics on many of the modern infrastructure indicators were not available prior to 1990-1991, which may be due to their recent introduction and 
thin intensity in their use in the Indian economy prior to this period. The data on tax revenues of centre and states, GDP, are collected from the Handbook of Statistics on the Indian Economy of Reserve Bank of India (RBI). The statistics on population to convert GDP and revenue variables into their per capita terms along with the data on 6 other types of ICT-related infrastructure variables such as internet users per million, mobile cellular phones per million, fixed telephone subscriptions per million, fixed broadband subscriptions per million, access to electricity consumption per million are collected from the World Bank Development Indicators of the World Bank to form a composite of an ICT infrastructure variable through the use of principal component analysis (PCA). The statistics to capture the quality of governance, political, social and judicial system (overall average measure of institutional quality based on 5 major parameters and by replacing it with an aggregative overall 12 indicators) are drawn from Political Risk Services International Country Risk Guide (PRS) published by the PRS Group. ${ }^{25}$ An overall average high score on sum of all these parameters would imply lower risk or a favourable institutional, socioeconomic conditions and governance settings for an economy; while on the contrary, a lower score implies greater political risk. As an alternative to this, we had also substituted with the rule of law variables drawn from the World Bank Development Indicators. The study also consistently used VAT adoption dummy at the state level from the period 2005 for state indirect tax revenue and combined total tax revenue equations.

\section{Econometric results}

The two revenue models specified in the above Eqs. 1 and 2 relate to (1) being the per capita revenue function which is estimated in logarithmic term for easy of interpretation of its estimated parameters and (2) relates to the estimation of revenue effort. In the latter, tax revenue is normalised w.r.t. GDP and is directly estimated in ratio form without converting the variables in logarithmic form. This is done as a standard practice in many other studies, with the intent that it does not pose any interpretational problem.

Since the data used are time series in nature, before we decide to implement any relevant time series methods for the estimation of our tax revenue models, we investigated the unit root property of variables used in our models. It applies the traditional procedures such as Augmented Dickey-Fuller (ADF) and Phillips-Perron (PP) tests, the results for which are producedin Table 1. Both the procedures confirmed that

\footnotetext{
25 The PRS compiles the statistics on political risk by covering data on 12 broad areas. One time we considered aggregate of all those 12 indicators, and another time we considered only 6 governance indicators, viz. democratic accountability, government stability, law and order, corruption and bureaucratic quality and socio economic conditions. Bureaucratic quality captures the institutional strength and is a shock absorber that tends to minimise revisions of policy when governments change. High points are given to countries where the bureaucracy has the strength and expertise to govern without drastic changes in policy or interruptions in government services and are somewhat autonomous from political pressures and have an established mechanism for recruitment and training. The political risk puts lower score for countries having more corrupt administration, countries facing greater external risk, internal conflicts, military participation in politics, ethnic and religion tensions.
} 
Table 1 Unit root test results on logarithmic values of variables

\begin{tabular}{|c|c|c|c|c|}
\hline & \multicolumn{2}{|l|}{ In levels } & \multicolumn{2}{|c|}{$\begin{array}{l}\text { In differences of vari- } \\
\text { ables }\end{array}$} \\
\hline & $\mathrm{ADF}$ & PP & $\mathrm{ADF}$ & PP \\
\hline LRGDP per cap & 2.58 & 2.45 & $-4.50^{*}$ & $-4.56^{*}$ \\
\hline LICT infra & $-8.02 *$ & $-8.99 *$ & & \\
\hline LReal state indirect taxes per capita & 2.05 & 2.05 & $-4.21 *$ & $-4.17 *$ \\
\hline LReal combined indirect tax revenue per capita & 3.33 & 3.33 & $-4.08^{*}$ & $-4.08^{*}$ \\
\hline LReal combined direct tax revenue per capita & -1.90 & -1.57 & $-3.97 *$ & $-3.95^{*}$ \\
\hline LReal total tax revenue per capita & 1.50 & 1.50 & $-3.80^{*}$ & $-3.80^{*}$ \\
\hline LReal state indirect tax revenue to GDP & -.55 & -.45 & $-5.83^{*}$ & $-5.82 *$ \\
\hline LReal combined indirect tax revenue 2 GDP & -.61 & -.62 & $-4.71 *$ & $-4.70^{*}$ \\
\hline LReal combined direct tax revenue2GDP & -1.62 & -1.58 & $-4.32 *$ & $-4.32 *$ \\
\hline LReal total tax revenue to GDP & -.77 & -.90 & $-4.36^{*}$ & $-4.31 *$ \\
\hline LComposite political risk & $-3.23 * *$ & $-3.09 * *$ & & \\
\hline Ldependent to total population & .20 & 2.73 & $-2.92 * *$ & $-2.98 * *$ \\
\hline LRule of law & -1.48 & -1.48 & $-4.82 *$ & $-4.82^{*}$ \\
\hline Lprivate consumption expenditure per capita & 4.04 & 3.36 & $-4.20^{*}$ & $-4.21^{*}$ \\
\hline Lprivate consumption expenditure $2 \mathrm{GDP}$ & -1.91 & -2.10 & $-5.54 *$ & $-5.54 *$ \\
\hline RGDPgr & $-3.96^{*}$ & $-3.94 *$ & & \\
\hline Lshare of agriculture output in total & -2.07 & -1.47 & $-7.54 *$ & $-7.06^{*}$ \\
\hline Lshare of industry \& service output in total & -1.96 & -1.23 & $-8.21 *$ & $-6.96^{*}$ \\
\hline LTrade2GDP & -2.04 & -1.94 & $-4.35^{*}$ & $-4.40^{*}$ \\
\hline Linternet use & -1.04 & -2.44 & $-3.07 * *$ & $-3.20 * *$ \\
\hline
\end{tabular}

$* \& * *$ indicate significance at $1 \%, 5 \%$ levels

except two variables such as average of composite of political risk and growth rate of GDP, which are level stationary, all other variables are difference stationary, i.e. $I(1)$ as they are found to be first difference stationary, after taking one time difference of values from their respective previous values in the series. Since this suggests that there exists mixed order of integrated variables in our models simultaneously along with the issue of short sample period of analysis, thus, we tried to apply the ARDL approach to cointegration. This method is proven to be producing robust results even in presence of short sample observations. And this method is useful irrespective of the time series properties of the variables incorporated in the model whether integrated of order $I(1)$ or $I(0)$. We have also conducted sequential Bai-Perron test to trace if there exists any structural breaks in variables used in our per capita specification. These results are produced in Table 5 in the appendix.

Table 2 produces unit root test results of variables used in our revenue effort model without considering their logarithmic values. It shows that except growth rate variable, all the variables are found to be integrated of order one, i.e. $I(1)$. The 
Table 2 Unit root test results on variables in ratios without taking their logarithmic values

\begin{tabular}{|c|c|c|c|c|}
\hline & \multicolumn{2}{|l|}{ In levels } & \multicolumn{2}{|c|}{ In differences of variables } \\
\hline & $\mathrm{ADF}$ & PP & $\mathrm{ADF}$ & PP \\
\hline RGDP per cap & .38 & .81 & $-4.25^{*}$ & $-4.40 *$ \\
\hline Composite political risk & -2.36 & -2.58 & $-4.71 *$ & $-4.37 *$ \\
\hline ICT infra & -.34 & -.34 & $-5.67 *$ & $-5.67 *$ \\
\hline Real state indirect taxes per capita & -.95 & .05 & $-4.37 *$ & $-3.18 * *$ \\
\hline Real combined indirect tax revenue per capita & .09 & 1.26 & $-3.98 *$ & $-5.01 *$ \\
\hline Real combined direct tax revenue per capita & -1.59 & -1.35 & $-3.54 * *$ & $-3.47 * * *$ \\
\hline Real total tax revenue per capita & -.21 & .20 & $-4.29 *$ & $-3.92 * *$ \\
\hline Real state indirect tax revenue to GDP & .73 & -.89 & $-4.20 *$ & $-4.13^{*}$ \\
\hline Real combined indirect tax revenue $2 \mathrm{GDP}$ & -.83 & -1.56 & $-5.09 *$ & $-5.31 *$ \\
\hline Real combined direct tax revenue2GDP & -.85 & -1.05 & $-3.53 *$ & $-3.51 *$ \\
\hline Real total tax revenue to GDP & -0.73 & -.89 & $-4.20 *$ & $-4.13^{*}$ \\
\hline Dependent population to total population & .24 & 2.17 & $-3.06^{*}$ & $-2.98 * *$ \\
\hline LRule of law & -1.00 & -1.01 & $-5.03 *$ & $-5.03 *$ \\
\hline RGDPgr & $-3.96 *$ & $-3.94 *$ & & \\
\hline Share of agriculture output in total & -1.83 & -1.12 & $-8.02 *$ & $-7.62 *$ \\
\hline Share of industry \& service output in total & -1.74 & -1.12 & $-8.02 *$ & $-7.62 *$ \\
\hline Trade2GDP & -1.43 & -1.42 & $-4.39 *$ & $-4.43 *$ \\
\hline
\end{tabular}

$*$, ** \& ***indicate significance at $1 \%, 5 \%$ and $10 \%$ levels

corresponding variables' sequential Bai-Perron multiple structural break test results are also presented in "Appendix" Table 6. Considering the resultant break dates as exogenous, we generated the dummies since those break period, so as to capture their effects in our model for removing any estimational biasness or the misspecification error. $^{26}$

At first we conducted the test of cointegration using the ARDL technique on our revenue per capita model. This is carried out with respect to when the dependent variable is substituted with combined direct tax revenues (column 2), combined indirect tax revenue (column 3), state indirect tax revenues (column 4) and then combined total revenues (column 5) for two higher most tiers of governments and are reported in Table 3. In order to take care of the structural features of the economy; we have incorporated the incomes or outputs generated in agricultural sector as percentage to total GDP as this largely falls outside the purview of direct and indirect taxation. The cointegration test result in the form of $F$-statistic confirms the presence of cointegration in all the per capita revenue models with different types of taxes considered corresponding to both levels of governments. It shows the computed F-statistics exceed the tabulated $F$-statistics provided in Pesaran et al. (2001).

At first, estimating the long-run parameters of the combined direct tax revenue per capita model, it shows that ICT infrastructure instead of helping the government

\footnotetext{
${ }^{26}$ However, latter we found that these structural dummies are mostly insignificant and their removal does not bring any differences to our parameter estimates.
} 
to realise greater revenues from direct income sources, it has rather adversely affected the direct tax revenue realisation. This means introduction of ICT infrastructure instead of serving as an enabling measure in making it easy to file the income taxes from various sources of incomes, it has not helped the government to realise greater revenues collections from direct tax revenue sources. The composite governance quality measuring the overall institutional quality did not show significant effect on the revenue mobilisation. It is the per capita income and surprisingly the dependency ratio which exert positive and significant influence for greater direct revenue collections. The growth rate and openness exert positive impacts on direct tax revenue collections. It also shows that an increase in agricultural share has a negative impact on the combined direct tax revenues.

In contrast, the estimation of combined indirect tax revenues per capita shows that the composite indicator of ICT infrastructure has a significant and adverse impact similar to its impact on direct tax revenues. And composite of governance quality has no influence on combined indirect tax revenue per capita similar to its no impact on combined direct tax revenues. Further, It is both the levels of RGDP per capita and its growth rate which play significant positive influence on indirect tax revenue collection and surprisingly the trade openness is found to have no impact along with agricultural share and dependency ratio. This implies Indian economy in the process of taking part in the process of globalisation, by undertaking liberalisation measures in terms of cutting down its tariffs; this might have resulted in drastic reductions in realisation of indirect tax revenue collections for the combined governments. As a result, it has no significant contribution to indirect tax revenues comparing its positive impact on direct taxes.

When we estimate a similar model with respect to state indirect tax revenues per capita, it shows that governance quality index is significantly and negatively associated with indirect tax revenue realisation at the state level. This could reflect weak governance quality across the Indian states, which might have led to their falling indirect tax revenue realisation or a drastic deteriorating effect on revenue realisation. However, contrasting with respect to both combined direct and indirect tax revenue per capita, the ICT infrastructure shows no significant impact in generation of indirect tax revenues at the state levels. It is the increase in RGDP per capita income which significantly has helped the state governments to realise greater collection of revenues. More surprising is the result, about the effects of GDP growth rate which is not helping the states to generate greater revenues along with no significant contribution from increasing share of agricultural incomes. It also shows that the trade openness is not playing any significant role in realisation of indirect tax revenues at the state level along with the dependency ratio. The trade openness showing no significant impact on indirect tax revenues is quite surprising as the state governments mobilise greater revenues from the sale of imported crude oil and natural gas which constitute a major import basket of India.

We have also tried to estimate similar model with respect to the combined total tax revenues which comprises both the direct and indirect tax revenues for which the result is reported in the last column of Table 3. When the total revenue is considered 
in per capita terms, it shows that it is the total real GDP per capita which significantly and positively influences the per capita total revenues of both the combined governments. The institutional quality to capture the effects of governance quality does not play any role in total revenue collection for the combined government. And the composite ICT infrastructure consistently plays a negative and significant role in the mobilisation of combined total revenues for both the governments including UTs. While growth rate of GDP in overall does not play any important role for greater revenue mobilisation of combined government, the share of agriculture plays as a crucial adversary role for greater mobilisation of total revenues for the combined government. ${ }^{27}$ Trade openness does not influence the combined total revenues per capita of both the tiers of governments but surprisingly the dependency ratio turned out to exert a positive influence on the combined total tax revenues of both the governments.

The sign and significances of the ECM term point out that there is causality in the model running from independent variables to direct and indirect tax revenues of the combined government and the state governments. The ECM coefficients vary from 61 per cent to 82 per cent implying that if there are any short-run deviations from the trend path of dependent variables from their long-run equilibrium values, it takes more than a year to restore to their long-run equilibrium values. The short-run parameter estimates also show that there is some kind of consistency in parameter estimates in line with parameter estimates obtained in long-run in terms of their signs and significances. In particular, ICT infrastructures, GDP per capita and to some extent the trade openness, dependency ratio and share of agricultural output variables have the same signs and significances, except governance factor which plays a positive significant crucial role in realisation of total combined revenues in the short run.

In Table 4, we have considered the role of same set of factors including the structural change measured in terms of output share of agriculture sector, how they influence the tax efforts of the combined government of centre, states and UTs. Similar to the above exercise, we considered combined direct tax revenue as a percentage to GDP(column 2), combined indirect tax revenues as percentage to GDP(column 3) and combined total tax revenue as a percentage to GDP (Column 5) as alternative dependent variables. However, we are not able to produce the results on basis of Model 2 for the indirect tax revenue efforts of only states and UT governments as the model estimation did not find evidence of cointegration as observed from Column 4 with a low value of $F$-statistic, while there existed cointegration for other models.

Estimating the model for combined direct tax revenue as a ratio to GDP (Column 2 ), it shows that the composite governance quality measuring the overall institutional quality plays no significant role in realisation of greater direct revenue collection.

\footnotetext{
27 We tried to replace the share of combined services and industry output in place of agricultural output share. It was found to be insignificant. We also tried to incorporate various structural dummies related to tax policy changes like the dummies for the year of VAT implementation since (2005) and the break years as per Bai-Perron tests, but their inclusion did not produce significant coefficients for dummies and their exclusion also resulted in no difference to the estimation of our general model of revenues.
} 


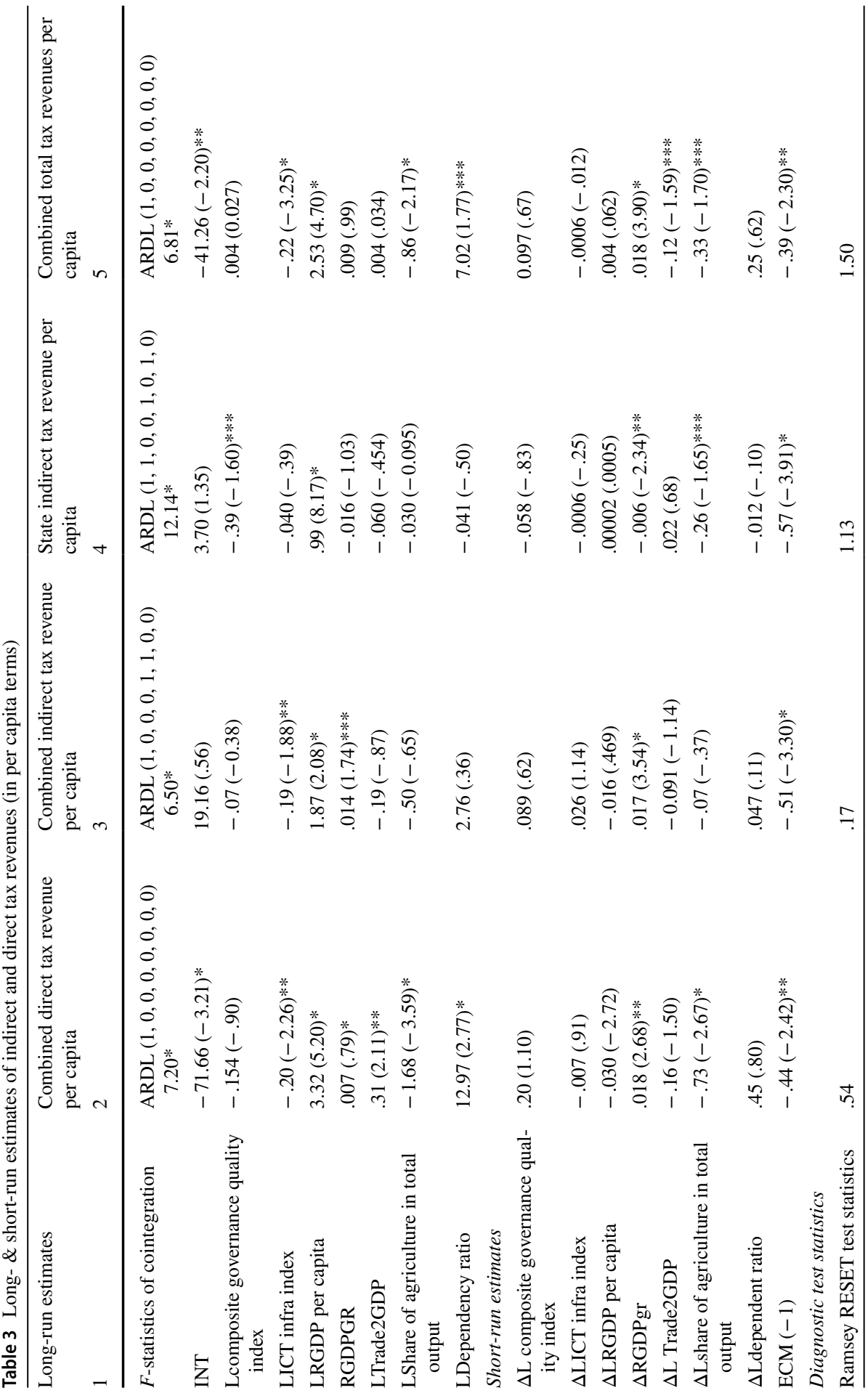




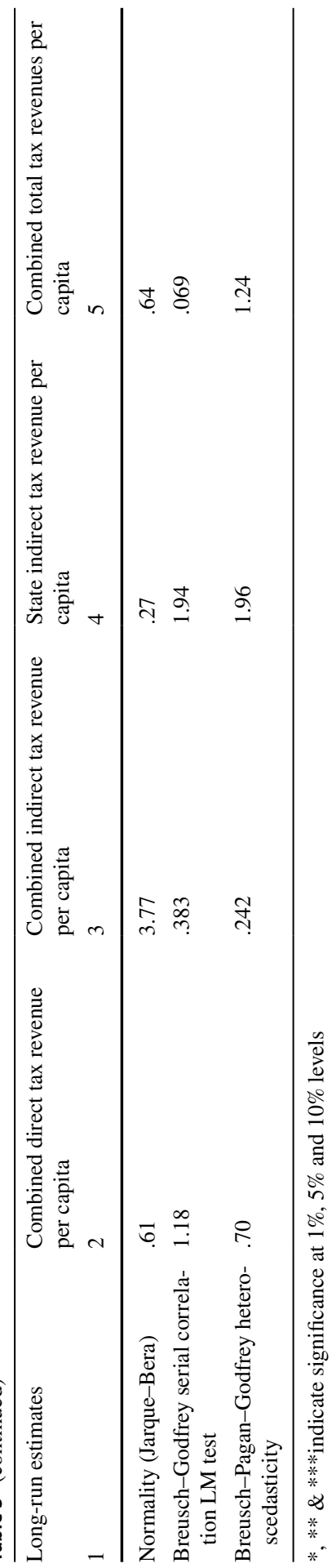


This again reflects poor quality administration of direct tax collection by the central government leading to no effect on the combined direct tax collection. It also shows that the ICT infrastructure instead of helping to realise greater revenues from direct income sources, it has rather adversely affected direct tax revenue collection. This means introduction of ICT infrastructure instead of serving as an enabling measure for greater reporting or filing of taxes on earnings from various sources, this has not helped the central government to realise greater revenues from direct tax sources. This might be due to the fact that tax payers might be concealing their income and carrying the transactions outside the purview of using the ICT infrastructures, so as to escape reporting or hide their true earnings. It is the per capita income and surprisingly the dependency ratio which exert positive and significant influences for greater direct revenue collections. ${ }^{28}$ The growth rate of income and openness exert positive impact on direct tax revenue collections. The trade openness leading to a rise of direct tax revenues efforts similar to the above could indirectly indicate that although effective corporate tax revenue has been falling over time in correspondence with global trend for most of the countries, however, as the countries compete for receiving greater foreign business and investment, and further when low corporate tax rate is combined with low tariff rates on imports of raw materials, those could prove as potential factors to attract business from outside. These factors sometimes can encourage the business inside and enable to generate employment and income and thereby adding to direct tax revenue generations from wage-based income sources. It is also shown that an increase in agricultural share has a negative impact on the combined direct tax revenues.

In contrast, the estimation of the combined indirect tax revenue effort (column 3) shows that neither governance/institutional quality nor the ICT infrastructure positively contributes to combined government indirect tax revenues. The composite index of ICT infrastructure plays no significant role unlike its negative impact on direct tax revenues, while the composite governance quality has a negative influence on the combined indirect tax revenue effort unlike its no impact on combined direct tax revenue effort. It is the GDP per capita along with dependency ratio which plays a positive and significant role in raising indirect tax revenue efforts. Surprisingly, the growth rate of GDP is found to be insignificant along with trade openness. This indicates that as India makes effort to gradually liberalise to remove the trade barriers by reducing the tariffs and other duties, the trade openness is not directly contributing to indirect tax revenues. This also gets reflected in our observed trends of indirect

\footnotetext{
28 The dependency ratio is having positive implication for direct taxes, and combined tax revenues could be established for the fact that having larger dependent members in a family could put pressure on the income earners to put additional efforts for earning additional incomes. And having more dependent members, it can contribute to more indirect tax revenue collection for the government as dependent members need to spend even if they do not have earning capacity. But this could be true that certain dependent members in the family also earn higher interest incomes on their past fixed deposits and other assets even after their retirement age, which can give rise to tax revenues. Moreover, from a macroeconomic perspective, if there is greater percentage of people are dependent in a society, government being responsible to serve the society in providing minimum services like education and health, it pressurises the government to collect more taxes from direct and indirect sources as well.
} 


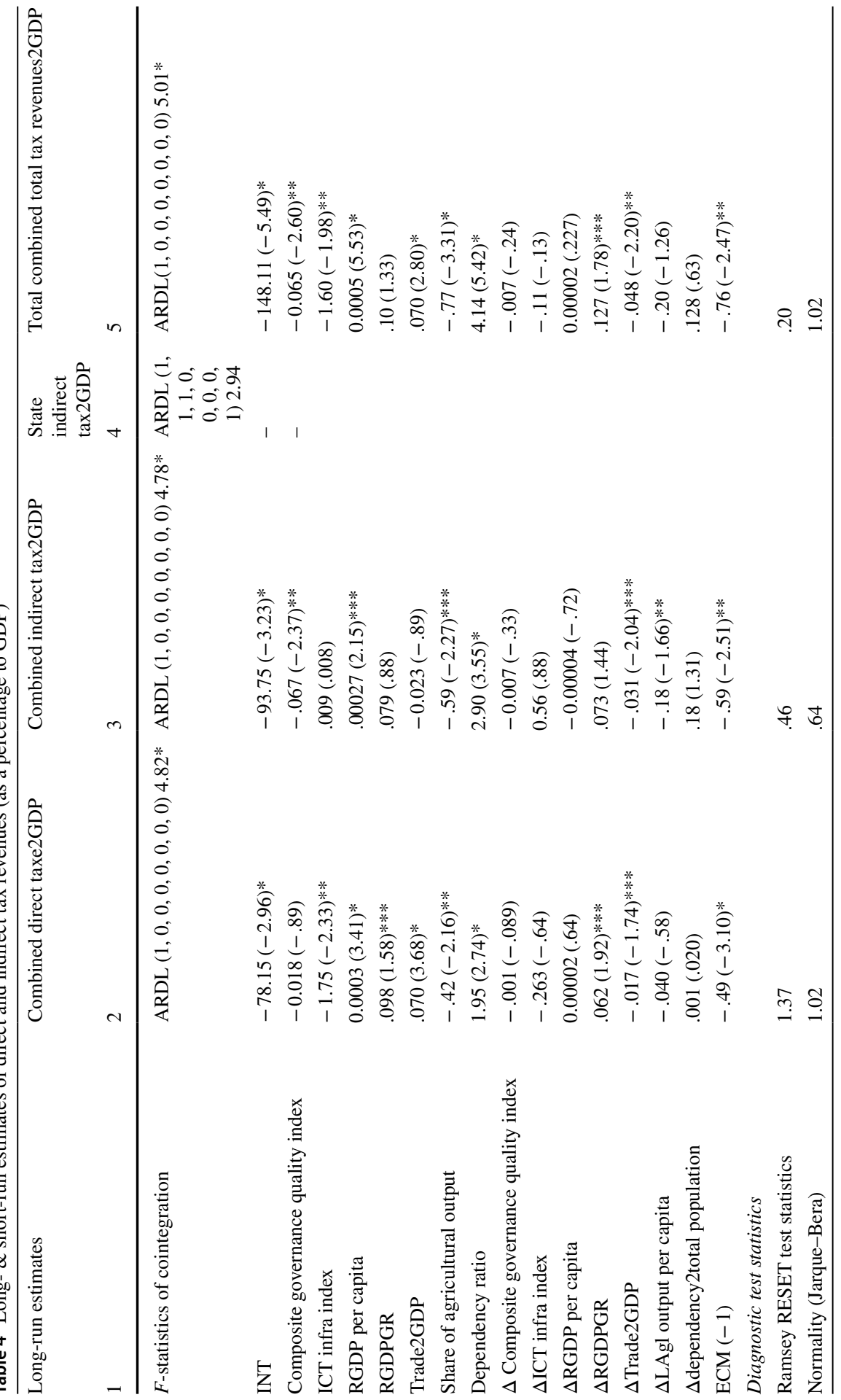




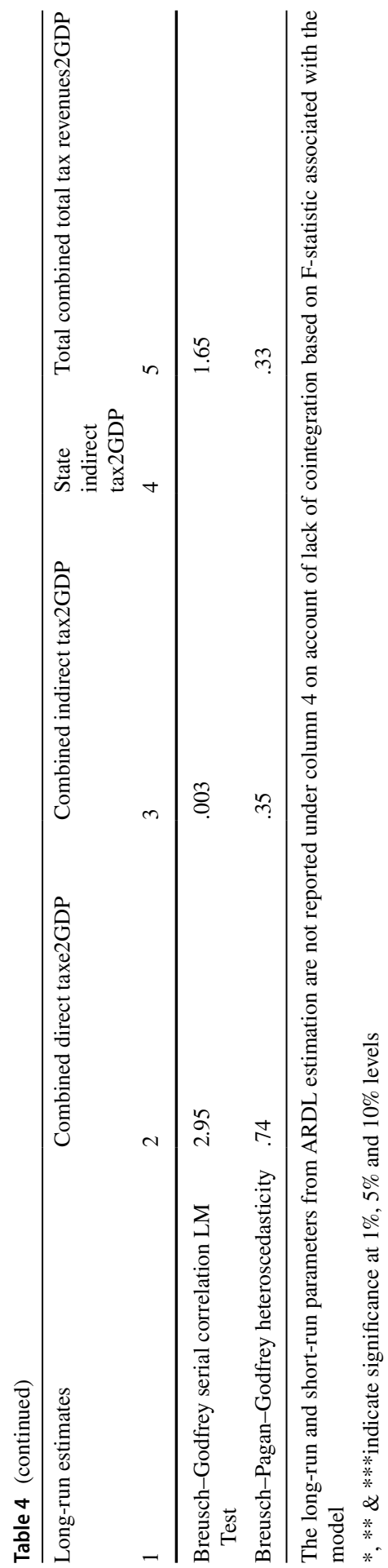


tax revenues as a proportion of GDP over the years. The share of agriculture sector has an adverse impact on indirect tax revenue effort.

When we estimate the total combined revenue of centre and states and UTs from both direct and indirect sources (Column 5), it shows that both the institutional setting (governance quality) and the ICT infrastructure significantly and negatively contribute to the combined total tax revenue collection efforts of the combined government. It is the per capita income and dependency pressure encourage the governments to put more tax revenue efforts, while a greater share of agriculture output neutralises the tax efforts. In overall, on account of liberalisation tendencies of the economy, the trade openness leads to making greater revenue efforts. The dependency is consistently putting pressure on tax effort of the combined government, which may be on account of its expanding size of the dependency population. The combined government greatly have to spend on higher education of the adults and address social security and healthcare needs of the elderly population.

In all the models were estimated, the ECM coefficients have relevant signs and significances reflecting there is causation running from one or more variables to the combined indirect and direct tax revenues to GDP proportions. The short-run adjustment coefficients vary from .49 to .76. This implies that it takes about half a year for the full adjustment to take place in case there is any short-run departure of the revenue efforts from their long-run equilibrium trends.

When we consider all the dependent revenue variables as a ratio to GDP, we observe governance and infrastructural quality instead of aiding to mobilise greater aggregate revenues for both the levels of governments, contrary to theoretical prediction, it results in either reduction of tax revenues or neutrality in revenue generations. This shows that the tax system of the country instead of harnessing the benefits from modern ICT infrastructural facilities for greater revenue productivity, it might be getting misutilised in the opposite direction either for manipulation or all the transactions are not feed into the ICT system to escape from taxation levies. In presence of a weak tax administration, tax payers might not be reporting their true incomes and sometimes they might be attempting to receive their incomes outside the ICT infrastructures. This calls for greater attention of the policy to redesign the governance in taxation system of the country towards making it more efficient and transparent which would go a long way to mobilise greater revenues and thereby contributing to the overall growth of the economy. The increase in agricultural income in total output results in less total tax revenue mobilisation. This is quite obvious as agricultural sector largely remains outside the purview of both the direct tax revenues and indirect tax revenues, and moreover, people with agricultural incomes; their pattern of consumption is such that they might not be consuming high value added products which otherwise might attract higher tax rates. The openness in trade is resulting in significant gains in direct tax revenues but is not leading to generation of indirect tax revenues and on net it shows a positive association with combined total tax revenues which could be due to its base effects.

Alternatively, when we adopted a general to specific approach in estimating both the Model A and Model B, we did not find much deviation from our above reported results. However, surprisingly with a minor deviation, the effects of institutional quality are found to exert a positive impact only for the combined direct tax revenue 
per capita as reported in "Appendix" Table 7 and the openness of trade which did not have an effect on the overall combined (direct and indirect) tax revenues per capita and state indirect tax revenue per capita. Similarly, when we tried to adopt specific model by retaining only governance and ICT infrastructures in our per capita revenue model, the results remain largely unaltered. And when we also tried similar models for ratio equation, most of our results seem to be consistent and the results for which are not reported for sake of brevity.

\section{Conclusion and policy suggestions}

In light of various reform measures undertaken in areas of direct and indirect taxes over the years more especially after the initiation of new economic reform measures encompassing broad changes in taxation policies such as implementation of VAT at the state level in 2005 and recently Goods and Services Tax (GST) in India from 1st July 2017 on the one hand and evolution in the use of ICT infrastructures on the other, current study attempts to assess whether governance and ICT infrastructures have played any significant roles in ways of mobilising greater revenues for the combined government of centre and states and UTs or those reform measures themselves are posing any major serious challenges for the tax administration of the country by dampening revenue collection potential.

It looked at both direct and indirect tax collection trends and tried to link up revenue mobilisation of combined and separate governments with ICT infrastructures by constructing a composite index of various infrastructures, by collating the data from World Bank Development Indicators along with an aggregative measure of governance (institutional quality) indicator of PRS Group from their International Country Political Risk Guide. It hypothesised that ICT infrastructure and governance might have aided the governments in achieving greater tax compliances, helping both the centre and states and UTs governments to realise greater tax revenues in India over the years. On the basis of empirical findings, finally it tried to offer some insights for the future tax policies.

The study tried to largely focus on post new economic policy reform phases, where lot of reform efforts are made with respect to both direct and indirect taxation. Thereby, it tried to cover sales tax, VAT and GST regimes by introducing dummy only for the State VAT regime since the year 2005. It assumed that introduction of new methods of collection of indirect taxes under GST regime is not completely different from previous VAT regime. This is how it extends to cover the period of analysis from 1990-1991 to 2017-2018 in a time series framework. Thereby, the current study makes an attempt to understand the role of ICT infrastructures and institutional/governance quality in understanding their contributions towards efficient revenue mobilisation. It comes out with the surprising (rather tantalising) evidence that there are greater weaknesses in areas of both governance and use of ICT infrastructures which have led to failings in realisation of greater tax revenues and tax efforts of the combined governments in India. Hence, it suggests the need for strengthening in both areas which can potentially contribute to greater tax revenue productivity. Greater penetration of ICT may not enable to generate greater amounts 
of revenues in a developing country like India unless people are compelled to do most of the transactions (above certain minimum ceilings) through banks and with the help of medium of ICT. In a developing country like India, where major portion of gross national income is generated in the informal sector, this may contribute to squeezing up the tax base. ${ }^{29}$ However, it is rather the increase in per capita GDP and dependency ratio which majorly have played key role in enhancing the tax revenues for the combined governments. And the increase in share of agricultural output has led to reduced tax revenues in India. Given that agriculture in recent years is giving rise to business at the higher end of value chain with emergence of processing industries and demand for the processed food, the government needs to think up these emerging areas for taxation.

Given the findings, it also tends to suggest that the ICT infrastructure alone may not lead to mobilisation of greater tax revenues, unless it is greatly supplemented with the governance quality and efficient administrative machinery to plug the loopholes and properly govern the taxation system of the country. It would be difficult to realise the potential revenue capacity unless corrective measures are put in place with respect to tax governance in particular and overall governance of the economy in general. While remedying the situation, it is the political, institutional and human capacity constraints may hinder the government to make innovation and go for any advanced solutions in the field of taxation. For instance, an existence of corrupt bureaucratic system can open up avenues for the dishonest taxpayers to bypass the digital systems to evade the taxes. The economies need to adapt and adjust with these changes. However, it is also true that while harnessing the modern ICT mediums, it may help the low income developing countries to leverage revenue generation comparable with advanced countries' potential capacity, thereby supporting their socioeconomic development. Further, the potential can be limited if large segments of the population lack access to digital advancement, which is happening elsewhere around the globe. Given that there exists a greater digital divide within the economy to access those modern facilities, therefore, the government should put necessary efforts in direction of ensuring universal accession to modern technology for the public which will not only help the private business to grow but also help the government in realisation of greater revenue potentials, and thereby ICT system acquiring the characteristics of public goods in a similar way that the WiFi connection is being provided in major cities covered under smart city mission program in India.

\footnotetext{
${ }^{29}$ It is also believed that improvement in ICT bank-based transactions by contributing to greater transparency in the system may help to widen the tax base by brining many informal sector activities into the fold of formal sector activity. Otherwise, many taxable activities would remain unnoticed by the tax authorities contributing to tax avoidance and less revenue realisation. This calls for further research on this policy sensitive issue.
} 
In sum, the study finds that the ICT infrastructure and governance taken separately do not majorly help in greater revenue mobilisation as expected. Introducing the reform into taxation system without correcting the loopholes in administration would have limited impact on revenue realisation. Modern technologies of tax collection would have limited role, unless tax administration assumes its effective role in ensuring efficiency in tax governance. Thus, tax reform implying better governance/administration should be at the fore. To quote Casanegra de Jantscher (1990), he pointed out that "the developing countries' tax administration is their tax policy" which highlights the critical role of tax administration in ensuring effectiveness of tax policy. However, the main limitation with this analysis is that it is aggregative at least for indirect tax revenues for the states and UTs. When it comes to collection of state tax revenues, the states primarily collect more indirect tax revenues than their direct revenues. As a result, their aggregate indirect revenue share in combined total indirect tax revenue is little less than the centre's share in the combined total indirect tax revenue collections. Given that the penetration of ICT infrastructure is likely to vary across the states, therefore, while examining the role of ICT infrastructure and governance in states' indirect tax revenue collection, one may analyse for a panel of individual states to take into account of state specific characteristics in tax revenue model. This may give more insights about whether the ICT infrastructure and governance factors have enabled the states in realisation of greater accrual of indirect tax revenues.

Acknowledgements I acknowledge Prof. Sunil Mani, Director of Centre for Development Studies (CDS) for encouraging me to contribute this piece of research study, realising its policy significance especially in the context of implementation of new indirect tax reforms (or GST) in India. I remain thankful to Mr. R. Mohanan and Prof. Manmohan Agarwal and other participants (including the doctoral researchers) in an open seminar at CDS for offering their valuable comments and suggestions. I acknowledge the helpful comments and suggestions received from the editor of the journal, Prof. George Hondroyiannis and the anonymous reviewer of the manuscript which helped to significantly revise the paper and bring into this present form.

\section{Appendix}

See Tables 5, 6, and 7. 
Table 5 Bai and Perron (2003) sequentially determined multiple break test on logarithmic values of variables corresponding to Model 1

\begin{tabular}{lll}
\hline & Break periods & \\
\hline LRGDP per cap & 1998 & 2006 \\
LICT infra & 1998 & 2002 \\
LReal State Indirect taxes per capita & 1999 & 2005 \\
LReal Combined indirect tax revenue per capita & 2002 & 2006 \\
LReal combined direct tax revenue per capita & 1994 & 1998 \\
LReal total tax revenue per capita & 1999 & 2005 \\
LReal state indirect tax revenue to GDP & 2004 & 2010 \\
LReal combined indirect tax revenue2GDP & 1994 & 1998 \\
LReal combined direct tax revenue2GDP & 1994 & 2004 \\
LReal total tax revenue to GDP & 2005 & \\
LComposite political risk & 1994 & 1998 \\
Ldependent to total population & 1998 & 2005 \\
LRule of law & 2002 & 2010 \\
RGDPgr & 2003 & \\
Lshare of agriculture output in Total & 1997 & 2002 \\
Lshare of Industry \& service output in Total & 1995 & 2002 \\
Ltrade2GDP & 1995 & 2004
\end{tabular}

Table 6 Bai and Perron (2003) sequentially determined multiple break test on variables corresponding to Model 2 without taking their logarithmic values

\begin{tabular}{lll}
\hline & \multicolumn{2}{l}{ Break periods } \\
\hline RGDP per cap & 2003 & 2009 \\
ICT infra & 2001 & 2010 \\
Real State Indirect taxes per capita & 2004 & 2010 \\
Real combined indirect tax revenue per capita & 1994 & 1998 \\
Real combined direct tax revenue per capita & 2004 & 2010 \\
Real total tax revenue per capita & 2002 & 2006 \\
Real state indirect tax revenue to GDP & 2004 & 2011 \\
Real combined indirect tax revenue2GDP & 1994 & 1998 \\
Real combined direct tax revenue2GDP & 1994 & 2004 \\
Real total tax revenue to GDP & 2005 & \\
Composite political risk & 1994 & 1998 \\
Dependent population to total population & 1998 & 2004 \\
LRule of law & 2002 & 2009 \\
RGDPgr & 2003 & \\
share of agriculture output in Total & 1995 & 2002 \\
share of Industry \& service output in Total & 1995 & 2002 \\
Trade2GDP & 1998 & 2004 \\
\hline
\end{tabular}

$*, * *$ and $* * *$ indicate significance at $1 \%, 5 \%$ and $10 \%$ levels 


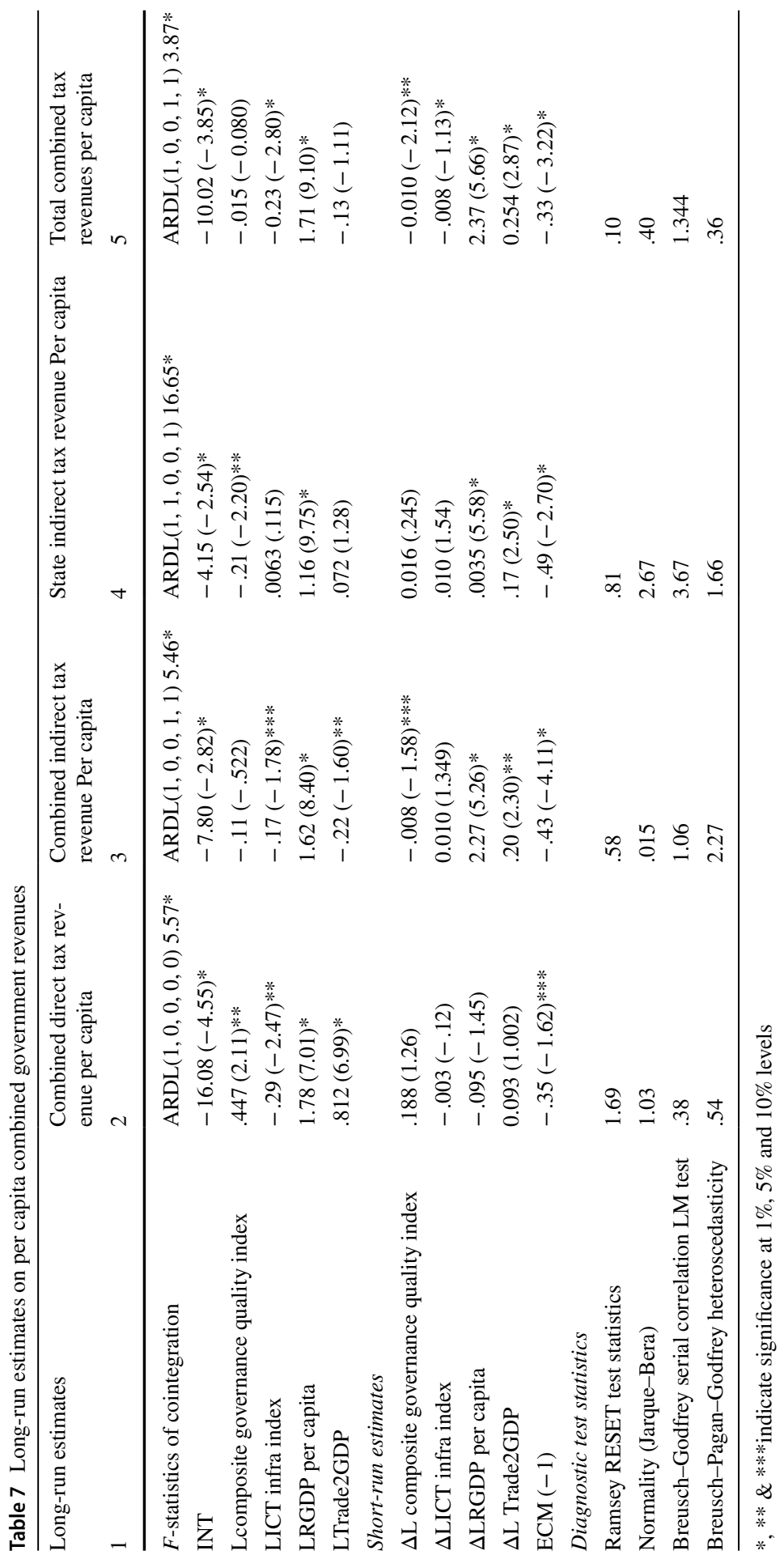




\section{References}

Alon I, Li S, Wu J (2018) Corruption, regime type, and economic growth. Public Finance Manag 16(4):332-361

Andreoni J, Erad B, Feinstein J (1998) Tax compliance. J Econ Lit 36(2):818-860

Arnone M, Iliopulos E (2007) The cost of corruption: economic, institutional and social effects. Vita e Pensiero, Milan

Bai J, Perron P (2003) Computation and analysis of multiple structural change models. J Appl Econ 18:1-22

Bagchi A (1994) Reform of domestic trade taxes in india: issues and options. Report of a Study Team, NIPFP, New Delhi

Belinga V, Benedek D, De Mooij R, Norregaard J (2014) Tax buoyancy in OECD countries. IMF Working Paper WP/14/110

Besley T, Persson T (2014) Why do developing countries tax so little? J Econ Perspect 28(4):99-120

Blackburn K, Bose N, Haque ME (2006) The incidence and persistence of corruption in economic development. J Econ Dyn Control 30(12):2447-2467

Bruno RL (2019) Tax enforcement, tax compliance and tax morale in transition economies: a theoretical model. Eur J Polit Econ 56:193-211

Campos J Edgardo, Lien D, Pradhan S (1999) The impact of corruption on investment: predictability matters. World Dev 27(6):1059-1067

Casanegra de Jantscher M (1990) Administering the VAT. In: Gillis M, Shoup CS, Sicat GP (eds) Valueadded taxation in developingcountries. The World Bank, Washington, DC

Census of India (2011) Ministry of Home Affairs, Office of the Registrar General \& Census Commissioner, Government of India

Comptroller and Auditor General (2010) Implementation of value added tax in india-lessons for transition to goods and services tax-a study report. Comptroller and Auditor General (CAG), GOI, New Delhi

Das-Gupta A (2012) An Assessment of the revenue impact of state-level VAT in India. Econ Polit wkly 47(10): 55-64

Dowe DE (2008) E-filing and E-payments - the way forward. In: Paper presented at Caribbean Organization of Tax Administration (COTA) General Assembly, Belize City

Dreher A, Herzfeld T (2005) The economic costs of corruption: a survey and new evidence. SSRN Electron J Mimeo. https://doi.org/10.2139/ssrn.734184 (Source: RePEc. Also accessible at https://econw pa.ub.uni-muenchen.de/econ-wp/pe/papers/0506/0506001.pdf)

Dzidonu CK (2012) Using information and communication technology (ICT) in managing national resources. In: Paper presented at the 7th internal audit forum, Accra

Evans C (2003) Studying the studies: an overview of recent research into taxation operating costs. eJ Tax Res 1:64-79

Fukuyama F (2013) What is governance? Centre for Global Development Working Paper N. 314

Gemmell N, Hasseldine J (2014) Taxpayers' behavioural responses and measures of tax compliance 'gaps': a critique and a new measure. Fisc Stud 35:275-296

Government of India (2019) Union Budget Document: 2019-20. Ministry of Finance, GOI

Government of India (2000) Union Budget:2000-01. Ministry of Finance, GOI

Government of India (2001) Report of the advisory group on tax policy and tax administration for the tenth plan under shome committee. Planning Commission, New Delhi

Hondroyiannis G, Papaoikonomou D (2017) The effect of card payments on VAT revenue: new evidence from Greece. Econ Lett 157(C):17-20

Hondroyiannis G, Papaoikonomou D (2018) Fiscal structural reforms: the effect of card payments on VAT revenue in the Euro area. Working Papers 249, Bank of Greece

Houssa R, Megersa K (2017) Institutional quality, economic development and the performance of VAT, Belgium Policy Research Group on Financing for Development (BEFIND). Working Paper No. 115, University of Namur

International Monetary Fund (2015) Current challenges in revenue mobilization: improving tax compliance. IMF staff policy paper

International Monetary Fund (2016) Corruption: costs and mitigation strategies. IMF staff discussion note, May 2016, SDN/16/05. https://www.imf.org/en/Publications/Staff-Discussion-Notes/Issue s/2016/12/31/Corruption-Costs-and-Mitigating-Strategies-43888 
Keen M, Lockwood B (2010) The value added tax: its causes and consequences. J Dev Econ 92:138-151

Keen M, Slemrod J (2017) Optimal tax administration. J Public Econ 152:133-142

Koyuncu C, Yilmaz R, Ünver M (2016) Does ICT penetration enhance tax revenue? Panel evidence. Anadolu Univ J Soc Sci 16(5):70-80. https://doi.org/10.18037/ausbd.417433

Mauro P (2004) The persistence of corruption and slow economic growth. IMF Staff Pap 51(1):1-8

Morrell K, Tuck P (2014) Governance, tax and folk tales. Account Organ Soc 39(2):134-147

Muralidharan K, Das J, Holla A, Mohpal A (2014) The fiscal cost of weak governance: evidence from teacher absence In India. Working Paper 20299, National Bureau of Economic Research. http:// www.nber.org/papers/w20299

Narayan PK (2003) The macroeconomic impact of the IMF recommended VAT policy for the Fiji economy: evidence from a CGE model. Rev Urban Reg Dev Stud 15(3):226-237

Oseni M (2015) Sustenance of tax administration by information and communications technology in Nigeria. Arch Bus Res 4(1):47-54

Pesaran MH, Shin Y, Smith RJ (2001) Bound testing approaches to the analysis of level relationships. J Appl Econ 16(3):289-326

Rajaraman I, Goyal R, Khundrakpam JK (2006) Tax buoyancy estimates for Indian states. Econ Polit Wkly 41:1570-1573

Ramsey FP (1927) A contribution to the theory of taxation. Econ J 37:47-61

Savica G, Dragojlovicb A, Vujoševica M, Arsicc M, Martica M (2015) Impact of the efficiency of the tax administration on tax evasion. Econ Res 28(1):1138-1148

Slemrod J (1989) The return to tax simplification: an econometric analysis. Public Finance Q 17:3-27

Tax Reform Committee (1991) Reports of the Tax Reform Committee, Ministry of Finance, Government of India, New Delhi

Transparency International (2019) Corruption perceptions index. International Secretariat, Germany. https://www.transparency.org/en/cpi/2019/results

Ugur M (2014) Corruption's direct effects on per-capita income growth: a meta-analysis. J Econ Surv 28(3):472-490

Ugur M, Dasgupta N (2011) Evidence on the economic growth impacts of corruption in low-income countries and beyond. EPPI-centre report 1914. Social Science Research Unit, Institute of Education, University of London

Van Rijckeghem C, Weder B (2002) Bureaucratic corruption and the rate of temptation: do wages in civil service affect corruption and by how much? In: Abed GT, Gupta S (eds) Governance, corruption, and economic performance. International Monetary Fund, Washington

Waseem M (2018) Taxes, informality and income shifting: evidence from a recent Pakistani tax reform. J Public Econ 157:41-77

Yitzhaki S (1979) A note on optimal taxation and administrative costs. Am Econ Rev 69:475-480

Publisher's Note Springer Nature remains neutral with regard to jurisdictional claims in published maps and institutional affiliations. 